\title{
The Origins and Expansion of the Male Breadwinner Family: The Case of Nineteenth-Century Britain
}

\author{
Sara Horrell and Jane Humphries
}

\section{INTRODUCTION}

The transition from a family economy in which incomes were democratically secured through the best efforts of all family members to one in which men supported dependent wives and children appears as a watershed in many otherwise very different histories of the family. It looms large in both orthodox economic analyses of historical trends in female participation rates and feminist depictions of a symbiotic structural relationship between inherited patriarchal relationships and nascent industrial capitalism. ${ }^{1}$ Both camps agree, as Creighton has recently put it, about "the outlines of [the] development" of the male breadwinner family. Where they disagree is in "the factors responsible for its origins and expansion". Why did families move away from an asserted "golden age" of egalitarian sourcing of incomes, which involved husbands, wives and children, to dependence on a male breadwinner who aspired to a family wage? Neoclassical economic historians emphasize the supply conditions, concentrating on income effects from men's earnings, family structure variables and alternatives to women's employment in terms of productive activities in the home. In contrast, dual systems theorists emphasize demand conditions in terms of institutional constraints on women's and children's employment exemplified by the exclusionary strategies of chauvinist trade unions, labour legislation which limited the opportunities of women and children, and the legitimation of men's wage demands by references to their need for a family wage. ${ }^{3}$ Our view is that systematic empirical investigation of the male breadwinner family has been lacking, ${ }^{4}$ even the timescale of its

' Peter H. Lindert and Jeffrey G. Williamson, "English Workers' Living Standards During the Industrial Revolution: A New Look", Economic History Review, XXVI (1983), pp. 125, exemplifies the neoclassical approach. Michele Barrett and Mary McIntosh, "The 'Family Wage': Some Problems for Socialists and Feminists", Capital and Class, 11 (1980) locates the emergence of the male breadwinner family within capitalist patriarchy, as does Jane Humphries, "Class Struggle and the Persistence of the Wotking Class Family", Cambridge Journal of Economics, 1 (1977), pp. 241-258, but these authors draw different conclusions. For an excellent recent reappraisal of the debated rise of the male breadwinner family, see Colin Creighton. "The Rise of the Male Breadwinner Family: A Reappraisal", Comparative Studies in Society and History, 38 (1996), pp. 310-337.

2 Creighton, "The Rise of the Male Breadwinner Family", p. 310.

${ }^{3}$ For a survey of the literature on the different routes to dependency see Katrina Honeyman and Jordan Goodman, "Women's Work, Gender Conflict, and Labour Markets in Europe, 1500-1900", Economic History Review, XLIV (1991), pp. 608-628.

4 This is surprising in that the English empirical tradition has been strongly evident in the historiography of women's work and the golden age controversy has been informed by a number of empirical studies based on British evidence. As in the evaluation of industrializa-

International Review of Social History 42 (1997), Supplement, pp. 25-64 
appearance and development remains obscure. ${ }^{5}$ Unless we fill in the outlines with more empirical detail we will never discover the reasons for its origins and expansion. ${ }^{6}$

This paper uses empirical evidence on the composition and adequacy of family incomes and men's wages to investigate the extent and growth of the male breadwinner family system during industrialization. The evidence is provided by an innovative dataset of British household budgets which detail household structure, income and expenditure for the years 1787 to 1865 . These budgets are used to investigate the extent to which families' incomes were compiled from the efforts of all members and to trace patterns across time, occupations and regions in the dependence on men and male earnings.

The results are surprising. For many families in a variety of economic circumstances the dependence on a male earner preceded industrialization. None the less, women, and more importantly children, continued to make significant contributions in some types of families and in many families at certain stages of the family life cycle. Close inspection of the empirical evidence suggests that there was no single set of circumstances which generated the male breadwinner family and that the nature of dependence on men and male wages was conditional on its specific origins. There seem to have been two routes to the male breadwinner family: a beneficent route through rising male wages, positive income effects and increased leisure for women and children, and a darker sequence involving the disappearance of locally available work for women and a descent into dependence and poverty. Legal, political and ideological institutions influenced women's and children's participation, particularly by the middle of the nineteenth century, and augmented the economic pressures promoting dependence on men and male wages. To emphasize the beneficent route to the male breadwinner family, with its corollary of a "preferred" and welfare enhancing dependence, and to neglect the appearance of a demand deficient dependence or institutional constraints on women's and children's work, with their less rosy implications for welfare, is to misrepresent the historical origins of a family form which remains a powerful ideological image even today.

Following a description of the family budgets, we use the data for husband-wife households to document the composition of family income for different occupations over the course of the Industrial Revolution. Then we investigate in more detail the importance of women's and children's

tion more generally, the British experience (for all its possible idiosyncrasies) poses as the archetype.

5The issue of timing is discussed in Jane Humphries, "Women and Paid Work", in June Purvis (ed.), Women's History: Britain, 1850-1945 (London, 1996), pp. 85-106.

- This paper takes up the injunction in Creighton's survey to develop an account of the development of the male breadwinner family which is sensitive to variations by region, trade and industry. 
earnings in supporting the family through certain phases of the life cycle, shading the male breadwinner story with longitudinal considerations. We note the importance of self-provisioning of goods and services and the need to include other sources of income as well as earnings. Next we explore the effect of industrialization on women's and children's labour force participation. Finally we provide a contrast to our husband-wife households by looking at families which lacked a male breadwinner. Absences of husbands and fathers, either temporary or permanent, left families dependent on the earnings of women and children. Yet men's absences were commonplace in the high mortality and economically insecure early industrial economy. Thus for all its growing dominance numerically, and even more important ideologically, most working people's lifetime experiences included some years lived outside the male breadwinner family.

\section{THE DATA}

We use a dataset of household budgets that detail household composition, sources of income (in kind or in cash), and the earnings of different family members as well as expenditures for the years 1787 to 1865 . The dataset has been compiled from 59 sources that include contemporary social commentators, Parliamentary Papers, local archives, provincial record offices and village autobiographies. ${ }^{7}$ Some of the sources are well known and widely quoted, others unpublished and unused. Neither type has been systematically analysed to reveal patterns in the composition of household income across sectors and over time during industrialization. These household accounts facilitate the investigation of the emergence of the male breadwinner household.

Where we focused on the composition of family income we selected only households containing a man and wife. This gave us a sample of 1,350 households distributed over time, place and occupation. The households varied in composition and in number of workers, both of which affected the level and structure of family incomes. We checked that the sample's household composition over time and across occupations was not grossly unrepresentative and so likely to distort conclusions about the evolution of incomes and changes in their sourcing. Our sample's average household size varied little over time, though it was larger than the 4.5 to 4.75 persons quoted as typical of the population as a whole, because of

'For full details of the sources, the information they contain, and the geographical, occupational and temporal distribution of the budgets see Sara Horrell and Jane Humphries, "Old Questions, New Data, and Alternative Perspectives: Families' Living Standards in the Industrial Revolution", Journal of Economic History, 52 (1992), pp. 849-880, appendix 1. 
our initial exclusion of single-person households. ${ }^{8}$ Aside from the two adults, most family members were children. Family composition varied by occupation broadly in line with expectations. Outworker, mining and factory families were larger than artisan, agricultural and casual labouring families.

There was no reason to expect the budgets that we had managed to collect to be a representative sample of the population. A preliminary investigation of the data confirmed the a priori expectation that families' economic experiences over the course of industrialization varied according to the occupation of the husband/father which proxied for a variety of local labour market conditions, and perhaps for cultural influences on family labour supply. But the occupational distribution of household heads in the sample was neither stable nor representative of the population as a whole. Our strategy was first to identify and describe the individual occupational experiences which could be checked against other occupationally-specific evidence, both quantitative and qualitative. Region also influenced income and earnings. Again, the sample of surviving records was not representative of the relevant population. Although the occupational categories in part captured this distinction, the a priori difference in the experience of agricultural labourers justified a further subdivision into high-wage and low-wage counties. ${ }^{9}$ The budget estimates of nominal male earnings exhibited reassuring similarities with existing wage series and earnings taken from detailed accounts of specific industries. ${ }^{10} \mathrm{~A}$ compar-

- Peter Laslett and Richard Wall (eds), Household and Family in Past Time (Cambridge, 1972); Peter Laslett, Family Life and Illicit Love in Earlier Generations: Essays in Historical Sociology (Cambridge, 1977); and Michael Anderson, Approaches to the History of the Western Family, 1500-1914 (London, 1980). For a full discussion of the comparison of household size from the budgets with other sources see Sara Horrell and Jane Humphries, " 'The Exploitation of Little Children': Child Labor and the Family Economy in the Industrial Revolution", Explorations in Economic History, 32 (1995), pp. 485-516.

The broad occupational breakdown for heads of household is as follows: agriculture subdivided into high- and low-wage counties according to E.H. Hunt, "Industrialization and Regional Inequality: Wages in Britain 1860-1914", Journal of Economic History, 46 (1986), pp. 935-966; mining and metalworkers; textile factory workers; outworkers (including handloom weavers, glove and stocking makers, silk weavers, framework knitters, winders, sewers, combers, shoemakers, tailors and nailers); trades (compositors, cutlers, carpenters, glaziers, masons, blacksmiths, millers, sawyers, coopers, carters, ostlers, spectacle framers, clerks and teachers); and casual and labouring jobs (railroad and road builders, dockyard workers and travellers).

${ }^{10}$ The full details of the comparisons made are discussed in Horrell and Humphries, "Old Questions", pp. 854-858 and are extensively documented in "Male Earnings Estimates from Household Accounts", available from the authors on request. For example, comparisons of occupational eamings were made with wage series taken from A.L. Bowley, "The Statistics of Wages in the United Kingdom During the Last Hundred Years: I. Agricultural Wages", Journal of the Royal Statistical Society, 61 (1898), pp. 702-722; M.W. Flinn, The History of the British Coal Industry. Vol. 2, 1700-1830 (Oxford, 1984); John Lyons, "Family Response to Economic Decline: Handloom Weavers in Early Nineteenth Century Lancashire", Research in Economic History, 12 (1989), pp. 45-91; G.H. Wood, "The 
ison of our occupational earnings with estimates constructed from wage data, and internal checks to ensure that the broad occupational categories were not biased by changes in intra-category skill levels or geographical locations, reinforced our confidence in the dataset and in the evidence on incomes from which the male earnings were extracted.

Subsequently the occupationally specific stories were recombined, using representative weights, to identify the average picture. ${ }^{11}$ Aggregated male earnings were compared with indices of nominal wages developed by other researchers. Overall growth rates appear similar. ${ }^{12}$ This confirmed that the weighting used to combine the occupational series into one representative of the working class was appropriate. That our men's wages moved in line with trends identified elsewhere further reassured us that the sample of household budgets was suitable for the investigation of family incomes and would produce reliable estimates of average trends.

\section{THE COMPOSITION OF FAMILY INCOMES}

Consider the proportion of family income contributed by the man in households which had both a husband and wife present and where the husband was in work, though perhaps not full work (Table 1). ${ }^{13}$ Men already contributed a high proportion of family income in many occupations on the eve of the Industrial Revolution. At this point democratic sourcing of income was largely a feature of factory and outworking families. Reduced contributions from the man can be observed in many occupations in the early $1800 \mathrm{~s}$, probably a consequence of war-related trade dislocation which entailed more reliance on other family members' earnings. But thereafter this tendency was reversed. From the 1830s onwards the dominance of male earnings was reasserted in families which had drifted towards more democratic earnings structures, such as those headed by

Statistics of Wages in the United Kingdom During the Nineteenth Century: XVI. The Cotton Industry Section II", Journal of the Royal Statistical Society (1910), pp. 128-163.

"For the employment weights used to construct the aggregate figures see Horrell and Humphries, "Old Questions", n. 40. The main sources used to calculate the national proportions of males in each occupation were Phyllis Deane and W.A. Cole, British Economic Growth 1688-1959 (Cambridge, 1962), p. 143; Brian Mitchell and Phyllis Deane, Abstract of British Historical Statistics (Cambridge, 1962), p. 60, and Peter H. Lindert, "English Occupations 1670-1811", Journal of Economic History, 40 (1980), pp. 702-704.

${ }_{12}$ Comparisons were made with Deane and Cole, British Economic Growth, p. 23; G.H. Wood, "The Course of Average Wages between 1790 and 1860", Economic Journal (1899), p. 59; and Lindert and Williamson, "English Workers' Living Standards", p. 7. For full details of these comparisons see Horrell and Humphries, "Old Questions", pp. 865-869.

${ }^{13}$ Continuous, annual data were not available and some years have only one or two observations, so we averaged over several years to mitigate this problem. 
men in low-wage agriculture, and began to mark occupational groups which had appeared initially less dependent on men and men's earnings, such as outworkers. In general a picture of increasing dependence on the adult male earner emerges, with the occupational attachment of the male head conditioning the pace and evenness of this trend. By the middle of the nineteenth century, on average, some four-fifths of family income was contributed by the husband/father. Families headed by men with factory jobs appear anomalous, retaining the shared responsibility for family income displayed in the late eighteenth century through industrialization.

The economy-wide trend may still have been away from a male breadwinner family form if more household heads were in occupational categories in which male earnings were relatively unimportant within their families. Although the economic restructuring associated with industrialization may have initially increased the relative weight of families headed by factory workers and outworkers, the declining importance of domestic industry by the second quarter of the nineteenth century, alongside the increased importance of artisan and mining families in which husbands'/ fathers' earnings were always dominant, implies that in aggregate the trend was away from more equal contributions to family income. The use of employment weights to aggregate the occupational trends confirms a deepening dependence on men and their earnings.

What do these untidy and occupationally specific patterns tell us about the origins of dependence? Was increased dependence on men a result of higher male eamings allowing women and children to withdraw from the labour market? Certainly the average picture seems to correlate closely with movements in real male earnings within the period. As earnings declined, the man's relative contribution fell suggesting the necessity of getting other household members into the labour force. As they rose from the 1830s, the trend reversed and the man's contribution increased. But such a clear picture is not discernible within and between occupations. The relationship is inverted for factory and mining families, suggesting a positive correlation between high wages and robust earning opportunities for family members. Moreover, relatively poorly-paid agricultural labourers contributed much higher percentages of their families' incomes than did men with better-paid jobs in mining and factories. The emergence of the male breadwinner family form seems to have been related to the availability of opportunities for other family members to earn as well as to the level of male earnings. ${ }^{14}$ In fact, in so far as high male earnings were positively correlated with plentiful employment opportunities for

14 Other empirical evidence suggests that working wives were not necessarily married to the poorest workers and that local labour market conditions could override predictions made solely from considering the family economy. For example, Savage has shown that, in Preston in 1881, the largest percentage of working wives were married to cotton and metalworkers and not to the least well-paid men: see M. Savage, The Dynamics of WorkingClass Politics: The Labour Movement in Preston, 1880-1940 (Cambridge, 1987). 
Table 1. Real male earnings and male earnings as \% family income

\begin{tabular}{|c|c|c|c|c|c|c|c|c|}
\hline & $\begin{array}{l}\text { High- } \\
\text { wage } \\
\text { agricul- } \\
\text { ture }\end{array}$ & $\begin{array}{l}\text { Low- } \\
\text { wage } \\
\text { agricul- } \\
\text { ture }\end{array}$ & Mining & Factory & Outwork & Trades & Casual & All $^{2}$ \\
\hline \multicolumn{9}{|c|}{ Male earnings as \% family income } \\
\hline $1787-1790$ & 86 & 74 & - & 53 & - & - & - & - \\
\hline $1791-1795$ & 89 & 77 & 70 & 58 & 47 & 77 & 82 & 73 \\
\hline $1796-1800$ & 84 & 70 & - & - & 60 & 64 & - & 68 \\
\hline $1806-1810$ & - & - & - & 77 & 57 & - & - & - \\
\hline $1811-1815$ & - & - & 85 & 73 & 54 & 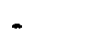 & - & - \\
\hline $1816-1820$ & 69 & - & 62 & 71 & 55 & 73 & 69 & 66 \\
\hline $1821-1825$ & - & - & 100 & - & 42 & - & - & - \\
\hline $1826-1830$ & - & 79 & - & - & 66 & - & - & - \\
\hline $1831-1835$ & 59 & 57 & 100 & 43 & 39 & 49 & 37 & 55 \\
\hline $1836-1840$ & 88 & 64 & 61 & 55 & 50 & 80 & 58 & 64 \\
\hline $1841-1845$ & 89 & 70 & 69 & 63 & 56 & 95 & 98 & 73 \\
\hline $1846-1850$ & - & 100 & 90 & 52 & - & 100 & - & 83 \\
\hline $1851-1855$ & - & - & - & - & - & 68 & - & - \\
\hline $1860-1865$ & 82 & 74 & - & - & 69 & - & - & 81 \\
\hline \multicolumn{9}{|c|}{ Real male earnings } \\
\hline $1787-1790$ & 25.34 & 22.59 & - & 39.31 & - & - & - & - \\
\hline 1791-1795 & 31.33 & 26.21 & 34.88 & 32.15 & 20.64 & 41.25 & 40.75 & 30.59 \\
\hline $1796-1800$ & 28.72 & 18.06 & - & - & 24.50 & 36.11 & - & 26.53 \\
\hline $1806-1810$ & - & - & - & 71.32 & 29.98 & - & - & - \\
\hline $1811-1815$ & - & - & 42.57 & 46.57 & 27.15 & - & - & - \\
\hline $1816-1820$ & 24.03 & - & 29.36 & 38.35 & 19.83 & 29.08 & 12.87 & 24.33 \\
\hline $1821-1825$ & - & - & 52.31 & - & 24.23 & - & - & - \\
\hline $1826-1830$ & - & 31.87 & - & - & 25.90 & - & - & - \\
\hline $1831-1835^{\circ}$ & 35.12 & 19.49 & 38.24 & 40.81 & 18.76 & 21.30 & 12.00 & 27.08 \\
\hline $1836-1840$ & 29.12 & 20.91 & 66.44 & 43.47 & 24.76 & 41.97 & 18.06 & 35.92 \\
\hline $1841-1845$ & 32.65 & 23.16 & 45.07 & 52.11 & 18.35 & 41.14 & 24.68 & 34.49 \\
\hline $1846-1850$ & - & 23.45 & 70.75 & 48.98 & - & 61.87 & - & 42.15 \\
\hline $1851-1855$ & - & - & - & - & - & 54.61 & - & - \\
\hline $1860-1865$ & 33.47 & 26.83 & - & - & 28.26 & - & - & 40.70 \\
\hline (Sample) & (176) & (325) & (98) & (78) & $(412)$ & (84) & (17) & (1190) \\
\hline
\end{tabular}

Notes:

'Weighted average using male employment weights, see $n$. 11 . The average is only calculated for those years where there is sufficient information on the individual occupations to make this possible.

busing cost of living index from Charles H. Feinstein, "Changes in Nominal Wages, the Cost of Living and Real Wages in the United Kingdom over Two Centuries, 1780-1990". in Peter Scholliers and Vera Zamagni (eds), Labour's Reward: Real Wages and Economic Change in 19th-and 20th-Century Europe (Aldershot, 1995), pp. 3-36; 1820-1824=100. 
women and children, the relationship between male earnings and men's contribution to family incomes may have been the opposite of that predicted by the standard income-effect. ${ }^{15}$

Figure 1 further subdivides family income into its component parts. ${ }^{16}$ With the exception of factory families, women and children do not appear to have increased their relative contributions to family incomes in most of the occupational groups. If anything there was a decline in their contributions, with increasing dependence on male earnings as its mirror image. Moreover male earnings appear to have increased in relative importance more than other family members' earnings contracted, as other income such as self-provisioning and poor relief declined from the modest levels seen in late eighteenth-century budgets. In so far as there was a heyday for the democratic sourcing of family incomes it appears to have been in the years after the Napoleonic wars and before 1835, though perhaps later for outworkers.

In general, it is clear that children's contributions exceeded those of their mothers. Only in low-wage agriculture in the middle of industrialization did wives and mothers match the contributions of their children. In agricultural families the relatively high participation rates of wives and mothers generated at most 5 per cent of family incomes in high-wage and 12 per cent in low-wage counties: clearly conveying the seasonal and discontinuous nature of the work undertaken. In mining families, married women's contributions were most important early on but even then constituted only around 8 per cent of income. Women who were married to men employed in factories also appear to have made small relative contributions except in certain exceptional families. Outworkers' wives added over 11 per cent during "the hungry forties" but their help was halved by mid-century. Artisans' wives were dependent on husbands' and other family members' earnings throughout the period. Only perhaps in lowwage agriculture and outworking families in certain periods did wives' and mothers' earnings make up over a tenth of families' incomes and even then children's earnings were as or more important.

${ }^{25}$ E.H. Hunt argues that the participation rates of women and children were positively correlated with men's eamings because high male eamings meant robust demand for labour which spilled over into women's and children's employment opportunities and pay rates: see E.H. Hunt, Regional Wage Variations in Britain, 1850-1914 (Oxford, 1973).

${ }^{16}$ The remaining components of household income were poor relief and income-in-kind, for instance gleaning and coal provided by the employer. Figure 1 demonstrates the relative unimportance of this other income beyond 1815 and outside the agricultural sector. Families were heavily dependent on eamings. Poor relief formed much the largest part of other income, but this was unimportant for factory, mining and outwork families and it is only found in 1821-1840 for our broadly defined trades families, constituting 7 per cent of total income. The main recipients were agricultural families, but it was less than 1 per cent of total income on average and was virtually non-existent by the final period. The exception was low-wage agriculture in 1821-1840 when 8 per cent of family income was from poor relief. 
Wives' earnings did not boost those of their husbands to generate significant increases in disposable income. From a rather uniform picture at the end of the eighteenth century, with wives contributing 3 to 10 per cent of family income across occupations, untidy and occupationally specific patterns developed: a fairly steady decline in high-wage agriculture and mining; growth and then decline in low-wage agriculture and outwork; perhaps some increase in families whose heads were employed in factories though the lack of observations in the later periods make this little more than guesswork; and stability in the archetypal male-breadwinner families of artisans. In almost all the groups married women's contributions were fading by mid-century and had anyway never been a mainstay of family incomes.

Was industrialization increasing children's earning opportunities and enabling them to contribute more to the family budget as industrialization proceeded (see Figure 1)? Children's contributions varied both by father's occupation and over time. In early industrialization, children in nonagricultural families did contribute more to household income than those in agricultural families, but the children of factory workers were not exceptional, if anything contributing less than their counterparts in other non-agricultural families. Children's contributions were largest in outworking families, corroborating the view that domestic industry witnessed the cusp of child employment. But children's earnings in these families represented only a third of total income. In general, the importance of children's earnings to the family economy declined, particularly after 1840 , but the gradient and pattern depended on the father's occupation. There was a rapid and monotonic decline in children's contributions in agricultural, mining, outworking and trades families, whereas their contributions to the families of factory workers were more sustained, but even here children contributed less in the final period.

The household budget evidence suggests that there was a large variation in the extent and development of dependence on men in the course of industrialization. Moreover, the variation in women's and children's contributions over time and across occupations was not consistently related to family income levels. Low-wage agricultural families at the beginning and the end of the period were among the poorest, yet wives' and children's percentage contributions were small relative to much better-off families whose fathers were employed in factories, for example, which suggests demand-side constraints: an interpretation reinforced by the evidence that as family real incomes in this sector struggled upwards after 1835 , wives and children contributed proportionally more not less. On the other hand, for miners' families the evidence is consistent with a story where increasing family incomes, driven by higher male earnings, purchased a relaxation of the efforts of wives and children. Symmetrically, stagnant male earnings perhaps enforced the persistently high contributions from other family members in outworking families. Artisans seem 
High-wage agriculture
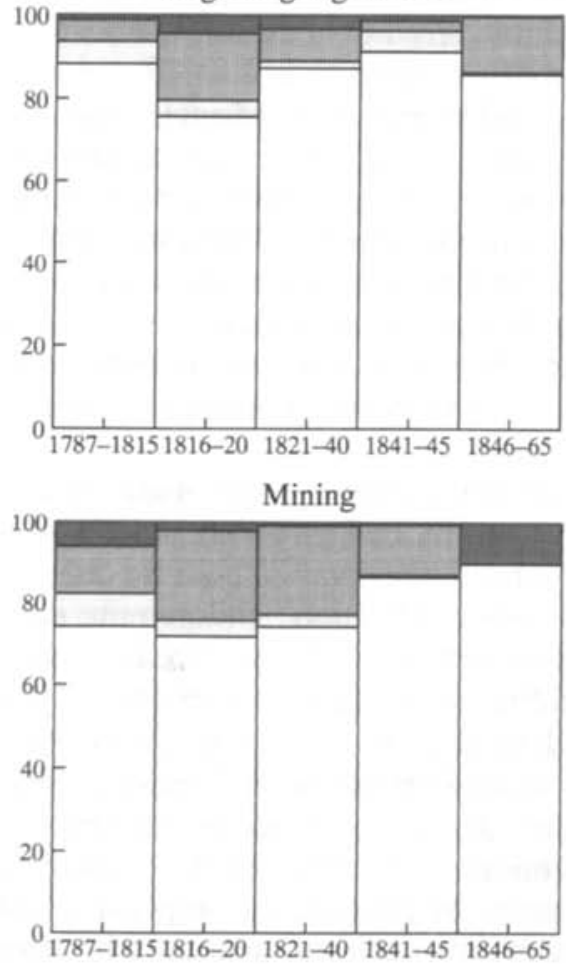

Outwork

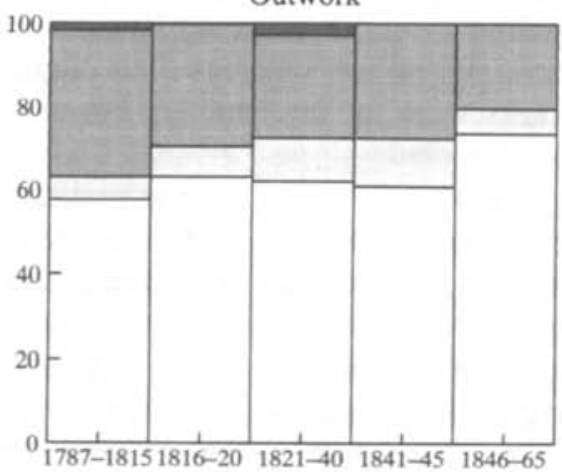

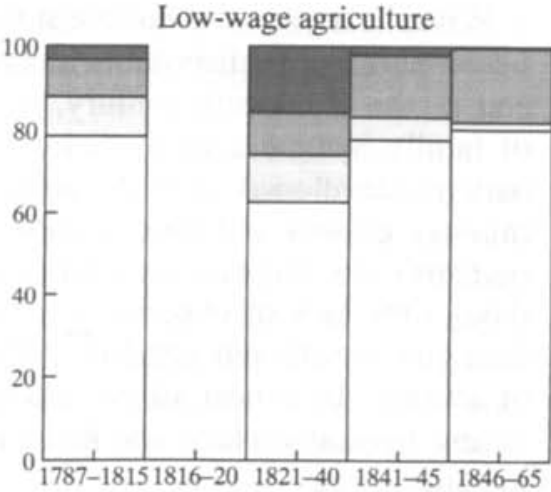

Factory

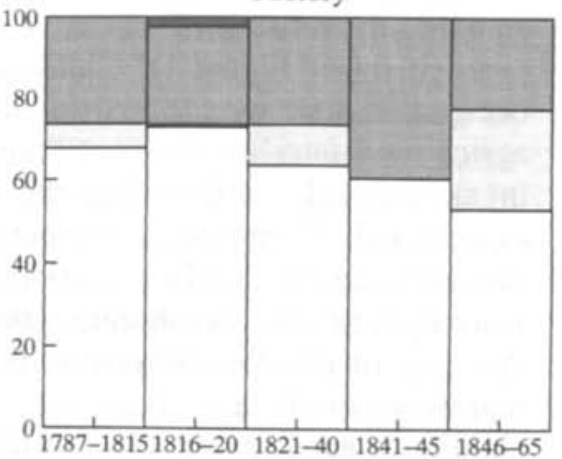

Trades

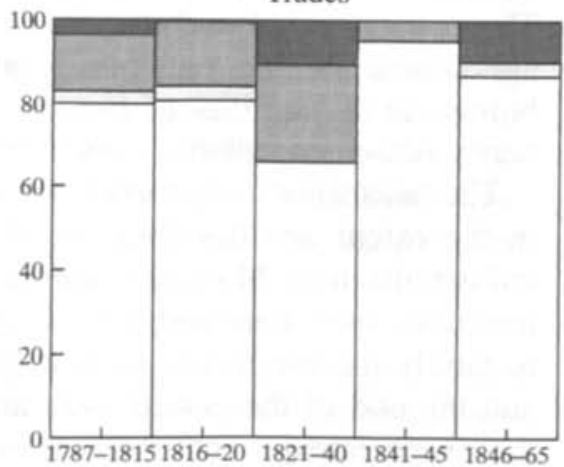

Figure 1. Contributions to household income (\%)

Notes: Other income is the residual after men's, women's and children's earnings are taken from total income. Women's and children's contributions are separated using the information on women's contributions, leaving children's as a residual. There is no information on the split of women's and children's earnings in the trades occupations in 1841-1845; the diagram shows the whole amount attributed to children.

Source: Sara Horrell and Jane Humphries. "Women's Labour Force Participation and the Transition to the Male-Breadwinner Family, 1790-1865". Eionomic History Review. XLVIII (1995). 
to have made an early transition to a family structure in which women's and children's earnings were relatively unimportant though they were not the highest earners and real male earnings did not increase until 1835.

These trends leave room for occupationally-specific, demand-based, institutional and ideological explanations. In particular, it appears likely that in the agricultural sector women and children were demand constrained in their attempts to contribute to family income. In mining protective labour legislation probably contributed to the withdrawal of women's and children's labour, a trend which simultaneously was underpinned by increasing male earnings, but there is little evidence that the early Factory Acts reduced children's economic contribution in families headed by men employed in factories. The experience of artisans suggests that a man's occupational status could carry with it ideas about appropriate employment patterns within families that were relatively independent of his earnings.

These preliminary findings have several implications. First, stories about women's and children's contributions to family incomes must be conditional on their occupational and regional identities, which limits "grand theorizations" of the origins and expansion of the male breadwinner family. Second, our analysis has also implicated institutions such as the law and cultural representations of fit work for women in the patchy development of dependence on men, themes pursued below. Third, within this heterogeneity of experience, one feature of husband-wife families stands out: while few families were entirely dependent on husbands and fathers, for most families male earnings were of crucial importance at the end of the eighteenth century and remained dominant through the Industrial Revolution. But this does not mean that women's and children's contributions were unimportant. First, the proportional contributions of women and children must be seen in the context of their relative earnings. At a time when a woman could earn perhaps one-third to one-half of a man's daily wage, an adolescent child perhaps the same, and a young child somewhat less, the levels of contribution recorded here suggest that, even before addressing issues like self-provisioning in which women and children probably specialized, women's and children's relative contributions in time exceeded their relative contributions in money. Second, although small on average relative to men's earnings, the contributions of women and children may have been crucial to most families during certain stages in the family life cycle, and to many families facing occasional but not uncommon critical life situations. The life cycle issue is addressed first.

\section{THE ADEQUACY OF MALE EARNINGS FOR FAMILY SUPPORT OVER THE LIFE CYCLE}

Is our picture of dependence on husbands and fathers a result of capturing families at certain stages of the life cycle when, for example, men's earn- 
ings were maximized in order to support small children and a childbearing wife? More generally, were men able to win most of the bread for growing numbers of children over the family life cycle? Did their earnings expand to accommodate increasing demands from a growing family? Or did women's and children's contributions play a key role in certain phases of a family's life? It is possible to investigate this issue using a sample of 296 budgets for 1816/1817 taken from two surveys conducted in Lancashire and Cheshire which systematically recorded the ages of husbands/ fathers and other family members. ${ }^{17}$

Although women's and children's earnings were on average small relative to men's for most occupations they were crucial in supporting the family through certain stages in its life cycle (Figure 2). Men's relative earnings declined in importance in the middle stages of the life cycle when children's earnings made up about one-third of income. Children's earnings were particularly important at this stage in mining, factory and outworking families. Women did not contribute much through earnings and there is evidence of a decrease in their relative contribution as children began to substitute for them in the labour market, an aspect discussed below. Women's earnings were particularly important in outworking families, where they were engaged in paid work and also supplemented income by taking in lodgers. In this sub-sample there were 26 lodgers, 24 of whom resided with outworking families, particularly families at younger stages in the life cycle and where family size was relatively large. Other income became more important as the household head aged. ${ }^{18}$ The occupational variation in life cycle patterns of dependence shades the occupationally-specific stories sketched above. The dependence in agricultural and trades families on the male earner is now seen to characterize the whole life cycle and the greater dependence on children's earnings in mining, outwork and factory families can be seen to reflect the importance of children's contributions even when the household head was elderly, which reflects a combination of both higher earnings and higher retention of children in families with these occupational ties.

The importance of children's earnings in life cycle patterns of income is highlighted when income is compared with the claims upon it (Figure 3). There is a close correlation between income and the number of adult

1 The surveys were taken from two unpublished sources: $A$ Census of the Poor of Ashton and Haydock, 1816, Warrington Library, Cheshire County Council and Tottington, Lancashire, A Survey of the Poor 1817, Manchester Public Library. The sample sizes for each occupation are: agriculture 30 , mining 51 , factory 15 , outwork 174 , trades 26 . They were combined to give an average picture using the male employment weights stated in Sara Horrell, "Home Demand and British Industrialization", Journal of Economic History, 56 (1996), pp. 561-604, n. 38.

is The exception is one factory family which had a lot of investment income in the $40-49$ age group. 


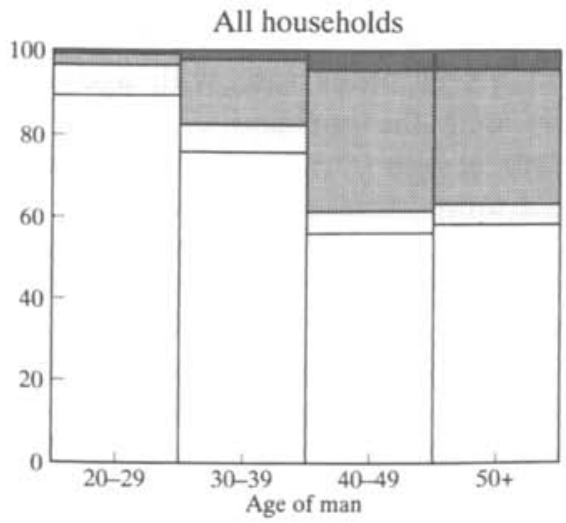

Agriculture
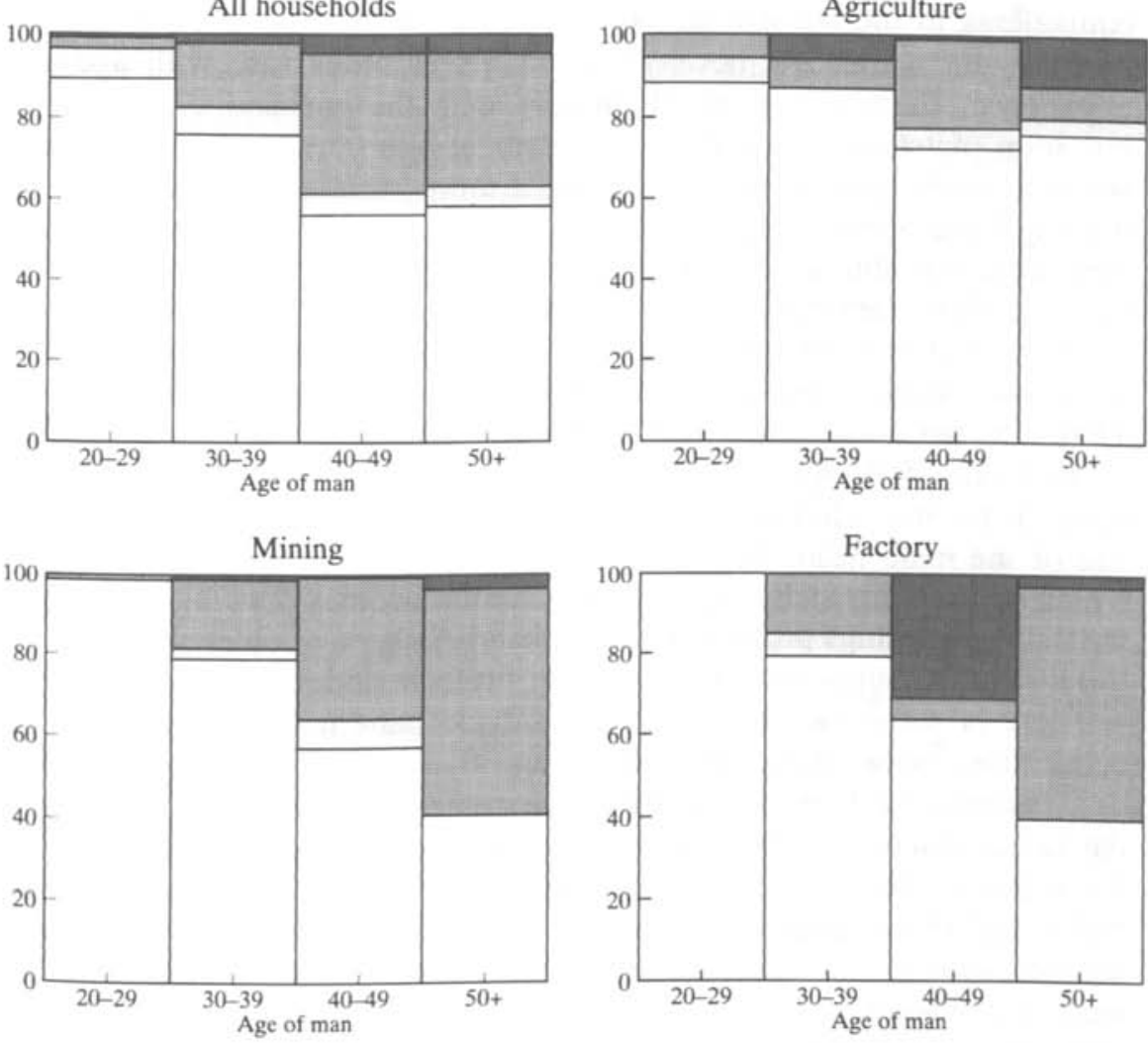

Outwork

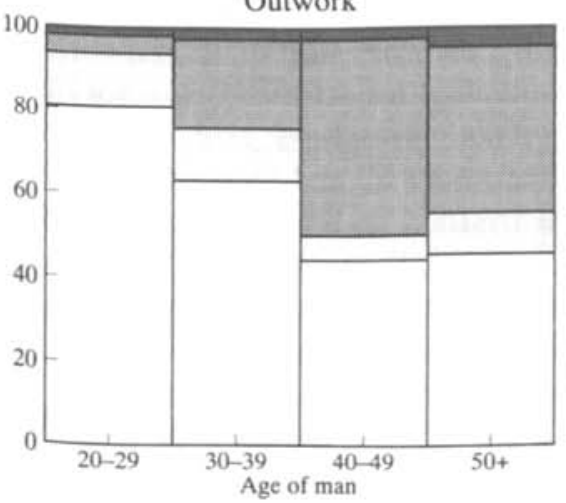

Trades
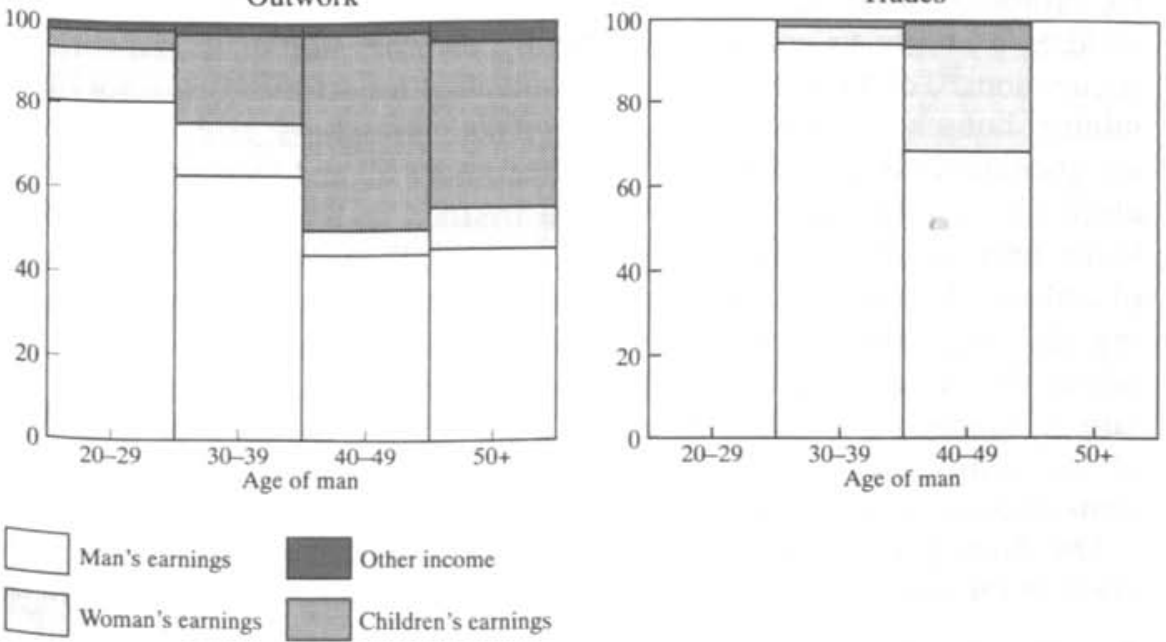

Figure 2. Life cycle composition of family income ( $\%$ total income) 
equivalents in the household. ${ }^{19}$ Income rose and fell in line with family demands on it, but not because the man's earnings rose with age and experience. Earnings increased initially with the husband's/father's age but soon plateaued out and fell from about age 45 . Adult male factory workers were exceptional in showing a more sustained rise of earnings with age. But apart from factory workers, in the early nineteenth century, men were not able to earn a family wage in the sense of being able to increase their eamings in line with the demands of a growing family. Instead it was women's and children's earnings which augmented incomes in the face of additional needs as family size and the ages of children rose. Thus after an initial slight fall in the very first stages of the family life cycle when adult equivalents rose faster than incomes (husbands/fathers aged 20 to 30 ), adult equivalent incomes stabilized through the middle age of the male head. But it was the eamings of other family members which ensured this stability, with total family incomes drawing away from the flat age-earnings profiles of the husbands/fathers, as older siblings contributed to the support of their younger brothers and sisters.

There is some variation in the life cycle pattern of contributions by occupation. Outworking, agricultural and trades families follow the standard pattern with family size and total incomes increasing pari passu until the father reached $45-50$ years of age by which time children started to leave home. The size of outworking families seems to have increased earlier and more rapidly than families headed by men in other jobs which accords with earlier marriage and consequent increased family size, but income per adult equivalent was stabilized by a slight increase in men's earnings accompanied by contributions from other family members. Thus the proto-industrial marriage pattern seems to have been underpinned by children's ability to contribute to family incomes earlier in outworking occupations. Total income and adult equivalent trajectories for factory and mining households have steeper gradients, household size and family incomes increase until the head was aged about 50 and then show a sharp drop. The children in families headed by men in these occupations left home later and had high earnings. In general, then, without the earnings of children, families in most occupational groups would have faced declining adult equivalent incomes in the middle years of the life cycle, declines which would have put pressure on the structure and functioning of the family. In this sense children's earnings played a key role in the evolution of the family as an institution by enabling it to continue to exist in a semi-nuclear form at least through the difficult years of the life cycle.

Our finding that children's earnings were important to the family's survival in the middle stages of its life cycle is consistent with the views of

19 Adult equivalents were calculated as man 1, wife 0.9 , child aged $11-140.9$, child 7-10 0.75 , child $4-60.4$, child $0-30.15$. These values were suggested in a US study for the late nineteenth century as given in Henry Higgs, "Workmen's Budgets". Journal of the Royal Statistical Society, 56 (1893), pp. 255-285. 

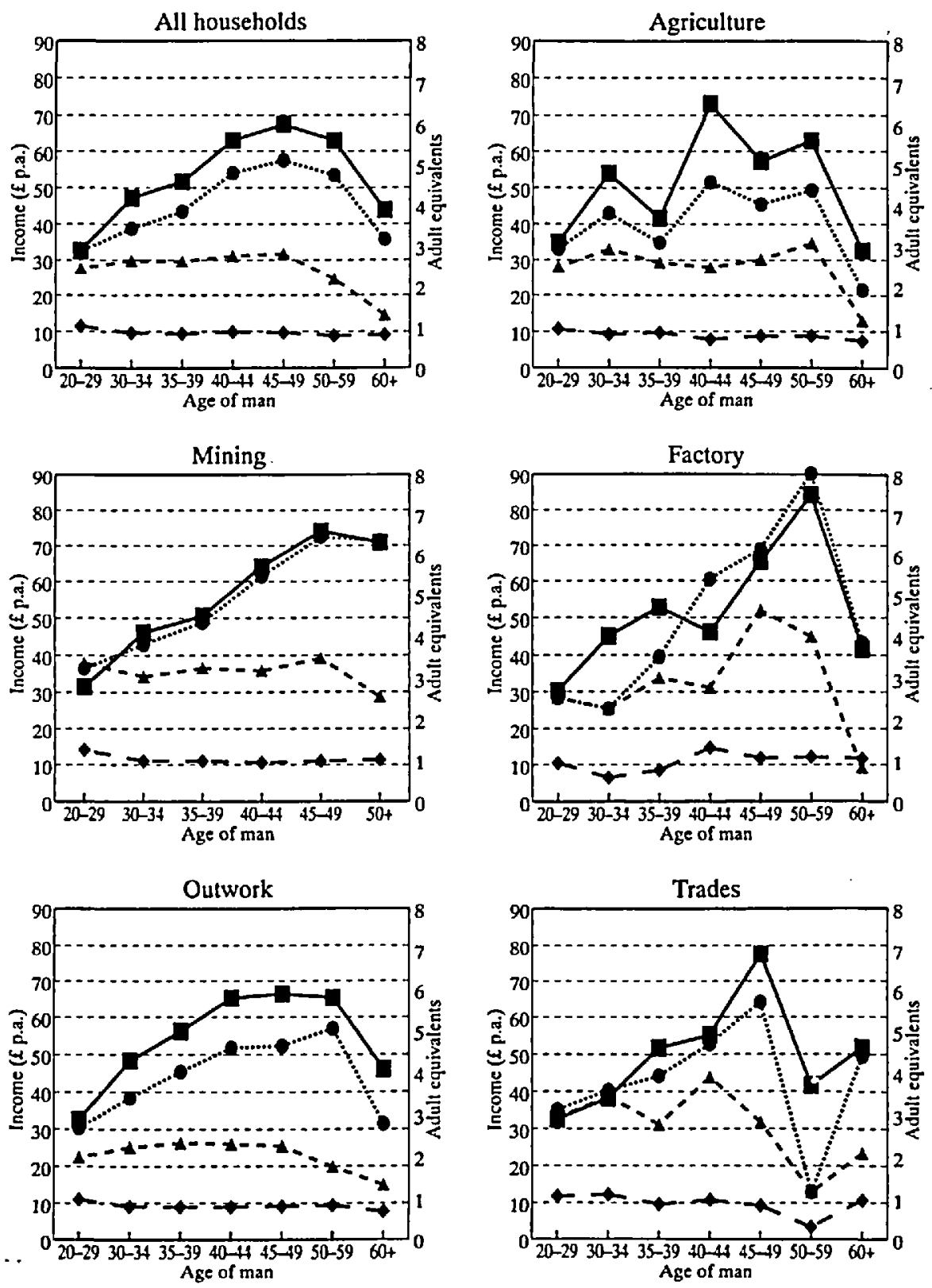

\footnotetext{
- Adult equivalents - $\$-$ Man's eamings

..... Total Income $\quad \longrightarrow$ Equivalent income
}

Figure 3. Family size and income over the life cycle 
nineteenth-century social commentators expressed in the context of the debate about child labour legislation. Anthony Austin, for example, in his survey of children's employment in various unregulated industries in Warrington in 1841, concluded that working children came from poorer families, ones where husbands were absent or ill, or where there was a large number of dependent siblings. ${ }^{20}$ Even in industries where men earned relatively high wages and a male breadwinner family was well developed, such as coalmining by the 1840 s, a large family still required older children to contribute. John Robertson, the pragmatic manager of a Scottish colliery in 1842, was well aware of the origins of pressures for children to work. He told the Royal Commission investigating children's employment in mines that he did not allow children under 12 years of age to be employed below ground "even if they are forward, unless it be necessary for the subsistence of some widowed mother or very large family".21 Those few working people themselves whose voices have been recorded on this topic cited the needs of large families and many small children in seeking to explain parental complicity in the employment of young children. As Isobel Wilson put it to the same Royal Commission, "when women have children thick (fast) they are compelled to take them down early". ${ }^{22}$ Parliamentary evidence suggests that parents were often desperately unhappy about the employment which their children undertook but felt that in the economic circumstances it was the best that could be done. ${ }^{23}$

Did the adequacy of male earnings to support families change over industrialization? Table 2 summarizes real adult equivalent male earnings from the budgets for each occupation over time. Real male earnings were low and declining relative to the number of adult equivalents in households for men in agriculture and trades until 1850 and for men with casual work throughout the whole period of industrialization. Factory workers' earnings were relatively high initially but in adult equivalent terms they too faced decline. The patterm in mining is strikingly different, male eamings were high and increasing throughout even when deflated by adult equivalents and were therefore capable of sustaining male breadwinner aspirations for these households. Adult equivalent real male earnings also improved for outworking families until the 1830 s, with cyclical interruptions, evidence of their "golden age"; but thereafter relative deterioration set in. The budgets provide little evidence that male earnings were rising relative to the demands upon them, and so increasingly able to support a family over time. The emergence of the male breadwinner family was not

20 Parliamentary Papers (hereafter PP), 1843, vol. XV.

2 PP, 1842, vol. XV, p. 19.

22 PP, 1842, vol. XVI, p. 461.

23 For a summary of relevant evidence, see Linda A. Pollock, Forgotten Children: ParentChild Relations from 1500 to 1900 (London, 1983), pp. 62-63 and Jane Humphries, "Protective Legislation, the Capitalist State and Working-Class Men: The Case of the 1842 Mines Regulation Act", Feminist Review, 7 (1981), pp. 1-33. 
Table 2. Real adult equivalent male earnings (I791-1795=100)

\begin{tabular}{|c|c|c|c|c|c|c|c|}
\hline & $\begin{array}{l}\text { High-wage } \\
\text { agriculture }\end{array}$ & $\begin{array}{l}\text { Low-wage } \\
\text { agriculture }\end{array}$ & Mining & Factory & Outwork & Trades & Casual \\
\hline $1787-1790$ & 82.3 & 94.9 & - & - & - & - & - \\
\hline 1791-1795 & 100.0 & 100.0 & 100.0 & 100.0 & 100.0 & 100.0 & 100.0 \\
\hline $1796-1800$ & 89. & 149.9 & - & - & 108.5 & 80.6 & 100.0 \\
\hline $1806-1810$ & - & - & - & 107.4 & 142.8 & - & $=$ \\
\hline $1811-1815$ & - & - & 160.4 & 70.1 & 129.8 & - & - \\
\hline $1816-1820$ & 76.0 & - & 88.4 & 56.2 & 88.6 & 73.1 & 34.4 \\
\hline $1821-1825$ & - & - & 200.2 & - & 115.3 & - & - \\
\hline $1826-1830$ & - & 166.6 & - & - & 159.3 & - & - \\
\hline $1831-1835$ & 118.5 & 85.0 & 98.2 & 37.8 & 78.5 & 46.0 & 31.5 \\
\hline $1836-1840$ & 96.4 & 86.3 & 153.4 & 86.9 & 128.9 & 104.1 & 45.1 \\
\hline $1841-1845$ & 93.7 & 86.6 & 176.2 & 61.8 & 92.6 & 74.1 & 61.1 \\
\hline $1846-1850$ & - & 130.2 & 230.6 & - & - & 250.1 & - \\
\hline $1851-1855$ & - & - & - & - & - & 156.0 & - \\
\hline $1860-1865$ & 133.3 & 108.9 & - & - & 150.2 & - & - \\
\hline \multicolumn{8}{|c|}{ Real adult equivalent male earnings ( $£$ p.a.) } \\
\hline $1791-1795$ & 8.43 & 7.09 & 8.29 & 17.95 & 5.68 & 10.67 & 12.74 \\
\hline (Sample) & (175) & (324) & (94) & (61) & (411) & (54) & (17) \\
\hline
\end{tabular}

Notes:

"Real earnings calculated using cost-of-living index from Feinstein, "Nominal Wages", p. 26. Adult equivalence scale uses 1.7 for man and wife and 0.5 for each other household member.

always or even usually accompanied by the payment of a family wage, so dependence on male earnings meant static standards if not hardship for members of many families.

This conclusion is further supported by analysis of expenditure for a sub-sample of households for which evidence was available (Table 3). ${ }^{24}$ The proportion of men's earnings spent on necessities (food and housing) was not decreasing over time, a pattern confirmed even when we control for increasing rents and changing family composition over time by considering adult equivalent expenditure on food as a proportion of the man's earnings. ${ }^{25}$ There was some improvement for some groups, but this was short-lived and for other occupations, such as outworking and agriculture, necessities were taking an increasing proportion of the man's earnings.

${ }^{24}$ For a detailed examination of the expenditure data from these household budgets see Horrell, "Home Demand".

25 Necessity expenditure is taken to be expenditure on bread, flour, potatoes, other grains, meat, lard, fish, eggs, cheese, milk, butter, tea, coffee, sugar, treacle and rent. Expenditure on fuel, clothing and other food was excluded to compensate for some element of discretionary, rather than subsistence, expenditure on food and housing. Adult equivalents were calculated as man 1 , wife 0.7 , other household members 0.5 as the ages of all members of the household were not always recorded in the surveys. 
Table 3. Expenditure on necessities from men's earnings (\%)

\begin{tabular}{|c|c|c|c|c|c|c|}
\hline & $\begin{array}{l}\text { High-wage } \\
\text { agriculture }\end{array}$ & $\begin{array}{l}\text { Low-wage } \\
\text { agriculture }\end{array}$ & Mining & Factory & Outwork & Trades \\
\hline \multicolumn{7}{|c|}{ Expenditure on food and housing as \% man's earnings } \\
\hline $1787-1796$ & 98.2 & 113.7 & 114.5 & 120.8 & 136.2 & 123.6 \\
\hline $1810-1817$ & - & - & 98.3 & - & 70.4 & 78.3 \\
\hline $1824-1825$ & - & - & 110.7 & 54.2 & - & - \\
\hline $1830-1840$ & 155.9 & 74.6 & - & 72.2 & 128.4 & 81.1 \\
\hline $1841-1854$ & 100.2 & 107.2 & 85.2 & 97.8 & 177.3 & 82.1 \\
\hline \multicolumn{7}{|c|}{ Adult equivalent expenditure on food as \% man's earnings } \\
\hline $1787-1796$ & 26.6 & 31.1 & 25.9 & 53.6 & 34.6 & 30.3 \\
\hline $1810-1817$ & - & - & 30.7 & - & 20.7 & 29.0 \\
\hline $1824-1825$ & - & - & 34.6 & 16.9 & - & - \\
\hline $1830-1840$ & 30.6 & 21.2 & - & 23.1 & 34.1 & 19.3 \\
\hline $1841-1854$ & 23.9 & 31.7 & 25.5 & 31.2 & 50.2 & 24.4 \\
\hline (Sample) & (45) & (93) & (29) & (37) & (37) & (13) \\
\hline
\end{tabular}

For groups experiencing improvement, such as trades and mining families, the transition to a male breadwinner household may have been eased, or even caused, by higher male earnings. In others, such as outworking and factory households where there had been an increasing reliance on the earnings of other family members, a decline in family work opportunities and increased dependence on the man alone must have been a painful transition. In only a few occupations were men earning enough to buy their families' sustenance and to provide the roof over their heads; for most households the earnings of women and children were essential and not becoming noticeably less so over time.

\section{SELF-PROVISIONING}

The eighteenth-century household had considerable opportunity to augment earnings through self-provisioning activities such as gleaning, growing potatoes, keeping a pig or cow, or collecting firewood; activities traditionally undertaken by women and children. ${ }^{26}$ Recently historians have rekindled interest in these activities, suggesting that they were important to the family economies of the poor and implying that they probably disappeared in the course of industrialization. Peter King, for example, has shown how through the period 1750 to 1850 , gleaning, a form of customary right that was almost exclusively the preserve of women, made a very

${ }^{26}$ R.W. Malcolmson, "Ways of Getting a Living in Eighteenth-Century England", in R.E. Pahl (ed.), On Work: Historical, Comparative and Theoretical Approaches (Oxford, 1988), pp. 48-60. 
considerable contribution to the annual income of labouring families. ${ }^{27}$ Jane Humphries has looked more broadly to suggest that the value of many gathering and self-provisioning activities undertaken by women and children has been underestimated by economic historians. ${ }^{28}$ Several authors have suggested that the ability of women and children to contribute directly to household resources probably declined alongside their earning power as access to common resources and the scope for selfprovisioning was curtailed by the enclosure movement, in particular, and the privatization of rural resources more generally. ${ }^{29}$ If this was the case then the broad social and economic movements which obliterated these activities and contributions also contributed to the emergence of the male breadwinner family. Variation in these movements across regions and economies may then help to explain the uneven development of dependence on men and its incompleteness even today in some areas and counties. Do the household budgets cast light on the hypothesized decline in selfprovisioning and its contribution to dependence on men and men's earnings?

The household accounts often noted self-provisioned produce, although a monetary value was not always imputed to it. The proportions of households for which some self-provisioning was reported are shown in Table $4{ }^{30}$ These proportions declined from the 1820 s onwards. Self-provisioning was important in the primary sector occupations and also to outworking families throughout the Industrial Revolution, but was rarely mentioned by families headed by men working in factories after 1800 . Most households only undertook one form of self-provisioning. Reporting more than one form of self-provisioning was more common before than after 1830 .

The form that self-provisioning took varied by occupation and over time. Not surprisingly gleaning largely occurred in low-wage agricultural counties, the arable south-east, but even here it was not common. Most

${ }^{27}$ Peter King, "Customary Rights and Women's Eamings: The Importance of Gleaning to the Rural Labouring Poor, 1750-1850", Economic History Review, XLIV (1991), pp. 461476.

${ }^{23}$ Jane Humphries, "Enclosures, Common Rights and Women: The Proletarianization of Families in Late Eighteenth and Early Nineteenth Century Britain", Journal of Economic History, 50 (1990), pp. 17-42.

${ }^{29}$ King argues that access to gleaning was reasonably constant from 1750 to 1850 but Humphries suggests that although gleaning was not strictly linked to common rights, it was more difficult to glean over enclosed fields than over open ones and of course the right to glean meant nothing if land was converted to pasture, so it too was threatened by enclosure. There is considerable evidence documenting the late eighteenth-century/early nineteenthcentury currailment of the poor's access to resources to self-provision: see Humphries, "Enclosures"; and J.M. Neeson, Commoners: Common Rights, Enclosure and Social Change in England, 1700-1820 (Cambridge, 1993).

${ }^{30}$ Only budgets taken from sources where some self-provisioning was mentioned were used for this analysis to avoid non-random bias in the collection of this information by commentators. 250 households engaged in some form of self-provisioning. 
Table 4. Self-provisioning activities

\begin{tabular}{|c|c|c|c|c|c|c|}
\hline & $\begin{array}{l}\text { High-wage } \\
\text { agriculture }\end{array}$ & $\begin{array}{l}\text { Low-wage } \\
\text { agriculture }\end{array}$ & Mining & Factory & Outwork & Trades \\
\hline \multicolumn{7}{|c|}{ \% households reporting self-provisioning activities } \\
\hline $1787-1800$ & 45 & 31 & 25 & 50 & 14 & 13 \\
\hline $1806-1820$ & 21 & - & 15 & 7 & 23 & 4 \\
\hline $1821-1830$ & $=$ & 100 & 100 & - & - & - \\
\hline $1831-1840$ & 41 & 14 & - & 9 & 33 & 20 \\
\hline $1841-1850$ & 25 & 71 & 64 & 0 & 19 & 0 \\
\hline $1851-1865$ & 28 & 16 & - & - & 0 & 67 \\
\hline (Sample) & (190) & $(320)$ & (93) & (30) & (221) & (45) \\
\hline \multicolumn{7}{|c|}{ Types of self-provisioning reported } \\
\hline $1787-1800$ & fuel/ale & fuel/pig/glean & fuel & fuel & $\begin{array}{l}\text { fuel/pig/ } \\
\text { pot }\end{array}$ & fuel \\
\hline $1806-1820$ & pot & - & pot/cow & pot & pot & pot \\
\hline $1821-1830$ & - & pig/pot & fuel & - & - & - \\
\hline $1831-1840$ & $\mathrm{pig} / \mathrm{pot} / \mathrm{cow}$ & glean & - & cow & pot & glean \\
\hline $1841-1850$ & pig/pot & pig/pot/cow & $\begin{array}{l}\text { fuel/pig/ } \\
\text { pot/cow }\end{array}$ & - & pot & - \\
\hline $1851-1865$ & pig/pot/cow & pig/pot & - & - & - & pig/pot \\
\hline \multicolumn{7}{|c|}{ Value of self-provisioning as \% men's earnings in self-provisioning households } \\
\hline $1787-1800$ & 7 & 13 & 3 & 3 & 53 & 3 \\
\hline $1806-1820$ & 6 & - & 15 & 3 & 4 & 4 \\
\hline $1821-1830$ & - & 14 & 2 & - & - & - \\
\hline $1831-1840$ & 16 & 8 & - & 23 & 6 & 3 \\
\hline $1841-1850$ & 29 & 31 & 10 & - & 9 & - \\
\hline $1851-1865$ & 19 & 11 & - & - & - & 9 \\
\hline
\end{tabular}

households collected fuel in the late eighteenth century but only miners did so by the nineteenth century. Increased urbanization, the enclosure of commons and wastelands and disappearance of estover and turbary, and cheaper coal which made collecting firewood or turfs less worthwhile, probably all contributed to the decline in self-provisioning of fuel. On the other hand, agricultural, mining and outworking households apparently turned with greater enthusiasm to growing potatoes. Factory and trades families' failure to cultivate potatoes clearly signals the lack of access to land in urban areas. Keeping a pig was a common activity in agricultural areas, but keeping a cow was confined to the higher paying rural occupations, high-wage agriculture and mining. Thus the extent of selfprovisioning declined with industrialization. Many households lost access to opportunities for engaging in these activities with increased urbanization and the static numbers employed in agriculture. With the exception of miners, occupations in which families could engage in lucrative rearing of livestock were in decline. Overall, industrialization reduced households' supplementation of income by the efforts of women and children in non- 
market forms of work. ${ }^{31}$ But how important had this contribution been? Did the loss of these activities hit working families hard?

The valuation of self-provisioning is difficult. ${ }^{32}$ Our budgets contain forty-two cases where values were ascribed to different types of selfprovisioning in different years. These accounts were used to impute values to the products of all self-provisioning, including those which were not valued in the sources. The value of self-provisioned goods in the sample

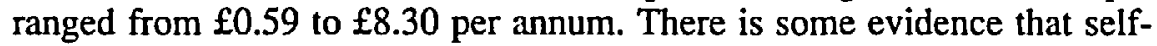
provisioning took on higher values over time in agricultural and mining households and lower values for secondary sector occupations. ${ }^{33} \mathrm{~A}$ useful comparison is with the male earnings in the households where selfprovisioning was undertaken. ${ }^{34}$ The increased importance of selfprovisioning to these households over time is apparent. The value reached nearly one-third of men's earnings in agricultural families in the 1840s and in most cases was greater than the contribution of women's earnings to the family. Self-provisioning was clearly an important way in which women and children augmented the household's resources. But, although self-provisioned produce represented a significant resource to those households which continued to enjoy it, self-provisioning's importance to households generally was declining over time as fewer households were involved in foraging, growing crops, keeping animals, gleaning and gathering. Averaged across all households, including those with no selfprovisioning, something less than 6 per cent of the man's wage, more often 2 per cent, was provided through self-provisioning in nonagricultural families, and although more important in agricultural families, particularly in low-wage agricultural areas, the decline in this form of contribution is visible from mid-nineteenth century onwards. The budget evidence cannot discriminate between the argument that families ceased to self-provision because it became inefficient as more productive employments became available, and the argument that families ceased to selfprovision because their access to resources was curtailed. The maintained and perhaps even enhanced value of subsistence production to those families which continued to self-provision follows in either case. But independent historical evidence on the paucity of opportunities for women and children to earn in the Victorian countryside, supports the second inter-

\footnotetext{
31 See Horrell, "Home Demand", for a discussion of how increased urbanization and a reduced proportion of the population engaged in primary sector occupations reduced selfprovisioning and increased expenditure on basic necessities.

32 See Humphries, "Enclosures", for a discussion of the issues and presentation of imputed values for self-provisioned produce.

${ }^{33}$ The number of occurrences of any type of self-provisioning are multiplied by the value ascribed, then all types of self-provisioning were summed and divided by the number of households recording at least one of these activities. This avoids inaccurately representing those households which record more than one form of self-provisioning.

${ }^{34}$ No obvious differences were observed in the incomes or male earnings of households according to whether they engaged in self-provisioning or not.
} 
pretation. Self-provisioning was probably not replaced by alternative more productive uses of time in southern agricultural districts characterized by under- and unemployment for women and children. Thus the likelihood is that the decline of self-provisioning left women and children increasingly dependent on earnings, and that meant on men.

\section{INDUSTRIALIZATION AND THE EMPLOYMENT OF WOMEN AND CHILDREN}

Women's labour force participation, defined as having either earnings and/ or occupation recorded in the budget source, shows occupationally, and, for agriculture, regionally, specific trends (Table 5). ${ }^{35}$ In all occupations the effects of the post-war depression in 1816-1820 on women's work opportunities is evident. While some of the decline may have been a consequence of the regional concentration of these observations some is undoubtedly real. Other authors have noted the severity of this downturn and the male earnings estimates from the budgets are comparable to alternative occupational series based on wider regional dispersions. ${ }^{36}$ The postwar dislocation had a common impact on women's work experience. Subsequently trends diverged.

The participation rates of women married to miners or casual workers appear to have declined during industrialization. The story is more ambiguous for agricultural labourers' wives. In high-wage agricultural areas women's participation declined then increased around mid-century, developments which are consistent with Ivy Pinchbeck's argument that allowances in aid of wages, made under the Old Poor Law, enabled agricultural labourers to maintain their wives and children despite their miserable earnings whereas the elimination of these subsidies by the New Poor Law forced wives in these families to seek employment. In low-wage counties, women's participation remained high but showed some tendency

35 For a full discussion of the use of this definition of participation see Sara Horrell and Jane Humphries, "Women's Labour Force Participation and the Transition to the MaleBreadwinner Family, 1790-1865", Economic History Review, XLVIII (1995), pp. 89-117. Here we use a subset of the husband-wife sample where the husband's eamings are positive and can be identified separately from those of women and children and where the male is employed in a known occupation (1,161 cases). We subdivide the years into five uneven sub-periods. This is a compromise between the conventional perception of a watershed in 1815 and our own interest in separating periods of economic recession, 1816-1820 and 1841-1845, from periods of relatively full employment. The occupation of the male head of household is still used as the organizing criterion as it is taken to be the best summary indicator of local economic conditions and specifically of the job opportunities and types of work available to other family members.

${ }^{36}$ Lindert and Williamson, "English Workers' Living Standards", p. 15, shows the severity of the post-war slump. For comparisons of male earnings from different sources, see Horrell and Humphries, "Old Questions", p. 854, table 6 and n. 25. 
Table 5. Married women's participation rates and earnings (earnings or occupation recorded)

\begin{tabular}{|c|c|c|c|c|c|c|c|c|}
\hline & $\begin{array}{l}\text { High- } \\
\text { wage } \\
\text { agricul- } \\
\text { ture }\end{array}$ & $\begin{array}{l}\text { Low- } \\
\text { wage } \\
\text { agricul- } \\
\text { ture }\end{array}$ & Mining & Factory & Outwork & Trades & Casual & All \\
\hline \multicolumn{9}{|c|}{ Participation rates $(\%)$} \\
\hline $1787-1815$ & $\mathbf{5 5}$ & 85 & 40 & 37 & 46 & 63 & 100 & 66 \\
\hline $1816-1820$ & 34 & n.a. & 28 & 4 & 42 & 30 & 67 & 49 \\
\hline $1821-1840$ & 22 & 85 & 33 & 86 & 54 & 63 & 67 & 62 \\
\hline $1841-1845$ & 40 & 56 & 9 & 100 & 73 & 100 & 0 & 58 \\
\hline $1846-1865$ & 48 & 63 & 0 & 100 & 69 & 43 & - & 45 \\
\hline (Sample) & (176) & (325) & (98) & (78) & (413) & (54) & (17) & (1161) \\
\hline \multicolumn{9}{|c|}{ Women's earnings as \% family income, where woman works only } \\
\hline $1787-1815$ & 9 & 11 & 41 & 23 & 15 & 5 & & \\
\hline $1816-1820$ & 17 & n.a. & 14 & 18 & 21 & 18 & & \\
\hline $1821-1840$ & 14 & 16 & 9 & 16 & 25 & n.a. & & \\
\hline $1841-1845$ & 13 & 10 & 9 & n.a. & 19 & n.a. & & \\
\hline $1846-1865$ & 13 & 13 & n.a. & 24 & 18 & 8 & & \\
\hline (Sample) & (37) & (153) & (20) & (16) & (141) & (12) & & \\
\hline
\end{tabular}

to decline after $1840 .{ }^{37}$ In contrast the participation rates of outworkers' wives increased after the 1816-1820 slump. Perhaps their contributions became increasingly necessary as male earnings were squeezed by falling piece-rates and competition from machine methods. ${ }^{38}$ Women in factory areas also showed steadily increasing participation after the post-war decline. The consequences of industrialization for women's work varied and any overall picture must depend on the weights attached to these individual experiences. ${ }^{39}$ The last column in Table 5 summarizes the occupationally weighted, aggregate participation series. This shows the sharp decline in participation in the post-war slump, the increase in the 1830s and further loss of jobs in the "hungry forties", a trend which continued after mid-century.

${ }^{37}$ Declining opportunities for women in agricultural areas after Waterloo are found elsewhere: see Robert C. Allen, Enclosure and the Yeoman (Oxford, 1991); K.D.M. Snell, Annals of the Labouring Poor: Social Change and Agrarian England, 1660-1900 (Cambridge, 1985).

${ }^{38}$ This would be consistent with the evidence of John Lyons, "Family Response to Economic Decline: Handloom Weavers in Early Nineteenth-Century Lancashire", Research in Economic History, 12 (1989), pp. 45-91.

${ }^{39}$ For a qualitative survey of women's work in several occupations largely supportive of our results, see Duncan Bythell, "Women in the Workforce", in Patrick K. O'Brien and Roland Quinault (eds). The Industrial Revolution and British Society (Cambridge, 1993), pp. 31-53. 
Overall, then, there is a suggested decline in participation. But these data do not, as yet, tell us anything about causation. Were women leaving the labour force voluntarily as husbands' incomes rose, or were they being driven out by discrimination or structural changes that reduced women's jobs? Certainly there was a decline in women's relative contribution to family income (see Figure 1). But was this decline simply the result of decreasing participation or was it the case that even considering only women who worked, their relative earnings were not maintained? A look at those working married women for whom earnings are separately identified suggests that while falling participation was one factor in the decline of women's relative contributions, the latter also fell (as in the case of mining), or rose and then fell (as in all other groups but factory workers) in the all-worker sample (see Table 5). ${ }^{40}$ Except for the wives of factory workers, married women who earned in 1816-1840 added larger percentage shares to incomes than those who worked after 1840. Women's earnings relative to men's earnings followed the same occupationally specific trends.

The variation in relative earnings power over time and across occupations might help to explain the patterns in participation. While for some occupations women's earnings increased relatively in the second quarter of the nineteenth century, for all occupations they grew less than men's (or children's) earnings after 1840. Perhaps it was married women's inability to hold their relative earnings positions even if they did work that fed the declining participation rates and not an exogenous decline in participation rates that drove their falling contributions to family incomes.

Neoclassical economic theory models the decision whether or not to work as the outcome of a rational weighing of alternatives with the goal being to maximize utility or satisfaction. ${ }^{41}$ Individuals, including married women, decide whether or not to participate in waged work by comparing the value of their time in the market (indexed by the wage rate) to the value of their time in the home ("the reservation wage"). ${ }^{42}$ The probability of participating is reduced to a function of own real wage, other real income, including husband's earnings (which affect the reservation wage) and a vector of variables to allow for constraints on the participation

40 The particularly small samples for factory workers' wives for 1816-1820 and 18461865 make it hard to comment on their experience.

${ }^{41}$ See Gary S. Becker, "A Theory of the Allocation of Time", Economic Journal, 80 (1965), pp. 493-517, and Jacob Mincer, "Labour Force Participation of Married Women: A Study of Labour Supply", in Alice Amsden (ed.), Women and Work (Harmondsworth, 1980), pp. 41-52.

${ }^{42}$ Major early empirical work on this topic includes: G.C. Cain, Married Women in the Labor Force (Chicago, 1966), and W.G. Bowen and T.A. Finnegan, The Economics of Labor Force Participation (Princeton, 1969). Reuben Gronau and James Heckman have contributed to the development of relevant statistical techniques: see, for example, the collection of papers in J.P. Smith (ed.), Female Labour Supply: Theory and Estimation (Princeton, 1980). 
Table 6. Probit regression of female participation

\begin{tabular}{lcc}
\hline Constant & -1.873 & $(-5.10)^{*}$ \\
Predicted female real earnings & 1.670 & $(15.31)^{*}$ \\
Male real earnings & -0.049 & $(-5.10)^{*}$ \\
Real income from parish & -0.071 & $(-2.16)^{*}$ \\
Other family members' real income & -0.031 & $(-4.42)^{*}$ \\
Child under 2 & 0.666 & $(4.33)^{*}$ \\
Number of children & -0.040 & $(-1.34)$ \\
Time & 0.065 & $(2.16)^{\star}$ \\
Time & -0.0034 & $(-3.59)^{*}$ \\
Time & 0.000023 & $(3.16)^{*}$ \\
Mining & -1.842 & $(-7.18)^{*}$ \\
Factory & -5.203 & $(-11.34)^{*}$ \\
Outwork & -3.713 & $(-13.19)^{*}$ \\
Trades & -1.406 & $(-5.01)^{*}$ \\
Casual & -1.017 & $(-2.37)^{*}$ \\
& & \\
Chi-squared & 555.6 & \\
Predicted correctly & $86.2 \%$ & \\
Sample size & 930 & \\
\hline
\end{tabular}

Notes:

- Participation defined as earnings recorded; t-ratios in parentheses.

- Indicates significance at 1 per cent level.

'Indicates significance at 5 per cent level.

decision and for heterogeneous tastes. Examples of the former include local employment opportunities, and of the latter, the number and ages of children and husband's work status conventionally assumed to imply "a taste" for home production. These variables should then be able to explain all the occupational and temporal differences in women's participation rates, with no role remaining for the influence of ideological and institutional factors. We use regression analysis to see how well these variables can explain the labour force participation of married women during industrialization and also include a time trend which is intended to capture other possible influences (Table 6). ${ }^{43}$

Perhaps surprisingly the conventional neoclassical model appears to fit the behaviour of our early industrial wives and mothers. Specifically women had a positive response to their own real earnings, whereas increased income from other sources reduced the probability of participation. Children had a negative effect on participation but having a child of under two years of age increased the probability of the woman working. The positive relationship between the presence of a baby and the probability of participating, so surprising in the context of contemporary studies, documents the historically important life cycle variation in women's work. Women worked during the early years of family formation but dropped

${ }^{43}$ The full explanation of the technique used can be found in Horrell and Humphries, "Women's Labour Force Participation". 
out when children matured enough to take their place in the labour market. ${ }^{44}$ Finally the cubic time trend is significant in all three terms. ${ }^{45}$ Calculation of turning-points showed a maximum in 1797 and a minimum beyond our period in 1871. Controlling for real earnings and income effects, the first half of the nineteenth century was associated with a rapid decline in the labour force participation of married women.

The significance of the time trend suggests that economic variables (wages and incomes) and household characteristics (numbers and ages of children) do not constitute a complete explanation of trends in women's participation rates. Omitted variables (changing institutional and ideological factors), operated to adversely affect women's participation. The trend follows the predominantly downward path indicated by aggregate participation in Table 5 and confirms the importance of exogenous factors in the overall picture of women's work during industrialization. But the patterns for individual occupations are not always the same as those for the whole sample, occupational specificity once more suggesting that any search for institutional and ideological obstacles to women's participation be conducted at the disaggregated level. Indeed disparate patterns would be expected from the timing of changes that occurred. Fears of replacement by cheap, female labour, evident in cotton spinning as early as 1818 , have been argued to be significant in the exclusion of women from wellpaid, expanding occupations as industrialization progressed and was institutionalized through legislation. In 1842 the Mines Regulation Act restricted the employment of women and children underground and the Ten Hour Act of 1847 limited their hours of work in factories; however, work in unregulated areas of employment continued until curtailment started with the 1867 Workshop Act. ${ }^{46}$ The chronology of the emergence of a male breadwinner ideology is more difficult to map. There was opposition to the assumption of dependency on a father's wage in the 1834 Poor Law Amendment Act, but by the later nineteenth century female

4 This effect is found in other historical studies: see Claudia Goldin, "Household and Market Production of Families in a Late Nineteenth Century American Town", Explorations in Economic History, 16 (1979), pp. 111-131; Elyce J. Rotella, "Women's Labor Force Participation and the Decline of the Family Economy in the United States", Explorations in Economic History, 17 (1980), pp. 95-117; A. Meyering, "La Petite Ouvrière Surmenée: Family Structure, Family Income and Women's Work in Nineteenth Century France", in Pat Hudson and W.R. Lee (eds), Women's Work in the Family Economy in Historical Perspective (Manchester, 1990), pp. 76-103. Modem studies would be more likely to interpret the negative relationship between the presence of children and participation in terms of the effects on the shadow price of time in the home.

43 The time trend is in three terms to allow for the possibility of changes in the effect of ideological and institutional influences over time.

${ }^{46}$ See Sonya O. Rose, "Gender Antagonism and Class Conflict: Exclusionary Strategies of Male Unionists in Nineteenth-Century Britain", Social History, XIII (1988), pp. 191208 for a detailed account of the exclusion of women from certain jobs, and Katrina Honeyman and Jordan Goodman, "Women's Work, Gender Conflict and Labour Markets in Europe 1500-1900", Economic History Review, XIIV (1991), pp. 608-628 for a general overview. 
domesticity and a male breadwinner became not only an accepted image but also a symbol of working-class respectability. ${ }^{47}$

What happened to children's work during the Industrial Revolution has also been fiercely debated. Economic historians appear to agree that the Industrial Revolution involved an increase in child labour, but the timing, nature, causes and consequences of this increase are not well established. ${ }^{48}$ Again systematic empirical investigation, hampered by the fragmentary nature of the data available, has not been undertaken. Some authors associate the increase in child labour with the spread of domestic industry. ${ }^{49}$ Other authors see factory production as promoting child labour.

Alongside the issue of the growth of child labour there is also the question of the age at which children started work. Part of the outrage over child employment in factories concerned the tender years at which children were employed. It was charged that children were starting work in factories much younger than they had customarily begun employment in agriculture or traditional manufacturing, and parents were accused of complicity in this infant exploitation. For instance, Sadler's Report of 1832 suggested that many children were supporting parents in idleness. ${ }^{30}$ But children in domestic industry also had been put "to work as soon as they were able to earn a few pence". Daniel Defoe, for example, mentions four-year-old children at work weaving wool. ${ }^{51}$ Perhaps the early nineteenth-century outrage about child labour did not occur because child labour was a new phenomenon, but because it was more visible, "more readily observable in the factory than in the obscurity of the cottage, the conditions and consequences of employment in the mills [...] were increasingly made a matter for concern". .2

Even if debate remains over whether or not children's participation in the labour market increased in total during the first three decades of the nineteenth century there is general agreement that by the 1840s it appeared

${ }^{47} \mathrm{~W}$. Seccombe, "Patriarchy Stabilized: The Construction of the Male Breadwinner Wage Norm in Nineteenth-Century Britain", Social History, XI (1986), pp. 53-76 gives an account of the transition, but argues that a male breadwinner ethos was only found in skilled trades prior to 1850. Sonya Rose, "Gender Antagonism", also discusses the emergence of the breadwinner ideology.

4 See, for example, J.L. Hammond and Barbara Hammond, The Town Labourer (London, 1932), p. 143; E.P. Thompson, The Making of the English Working Class (London, 1963), p. 331; Phyllis Deane and W.A. Cole, British Economic Growth, 1688-1959 (Cambridge, 1962), p. 294; Neil McKendrick, "Home Demand and Economic Growth: A New View of the Role of Women and Children in the Industrial Revolution", in Neil McKendrick (ed.), Historical Perspectives: Studies in English Thought and Society in Honour of JH. Plumb (London, 1974), p. 185; Clark Nardinelli, Child Labor in the Industrial Revolution (Indiana, 1990), p. 740; Pat Hudson, The Industrial Revolution (London, 1992), p. 124.

49 For example, Ivy Pinchbeck and Margaret Hewitt, Children in English Society. Vol. 2. From the Eighteenth Century to the Children Act 1948 (London, 1973).

so See Nardinelli, Child Labor, for a full discussion of this Parliamentary report.

s1 Pinchbeck and Hewitt, Children in English Society, p. 390; Defoe is cited in Louise A. Tilly and Joan W. Scott, Women, Work and Family (New York, 1978), p. 32.

${ }^{52}$ Pinchbeck and Hewitt, Children in English Society, p. 406. 
to have been in decline. Levine sees families in outwork as by then dependent on a male breadwinner who contributed around two-thirds of total income. ${ }^{53}$ The declining numbers of children employed in factories have been explained by both demand- and supply-side shifts associated with: the Factory Acts of 1833 and 1844; increased male real wages (in part a result of the exclusion of cheaper labour); and changes in technology which reduced demand for tasks performed by children. ${ }^{54}$ However, it is not known whether children displaced from factories found work elsewhere or remained unemployed, or whether their withdrawal from the labour force more generally was voluntary.

If industrialization did increase child labour through intensified participation and long hours worked in factories and mines and at outworking occupations, children's contributions to family income should have increased, muting tendencies towards dependence on men. Similarly the withdrawal of child labour from the 1840 s should have heralded increased dependence on a male breadwinner. We have already seen that trends in children's contributions to household income support this general interpretation. However, a closer look at the evolving patterns of children's work not only provides greater detail but begins to cut through to explanations of the trends observed. .s $^{\text {s }}$

Table 7 summarizes the evidence from the budgets on children's participation rates. ${ }^{56}$ What happened appears to have been conditional on father's occupation, as a proxy for local job opportunities and family attitudes, which helps to explain the diverse, and sometimes inconsistent, views about the effects of industrialization found in the literature.

In 1787-1816 the children of men with agricultural occupations, whether in high- or low-wage counties, had similar relatively low participation rates. Thereafter their experiences diverged. In low-wage counties, children's participation rates fell precipitously, while in high-wage counties, they increased and then declined: both patterns are consistent with trends in contributions, and with independent evidence of deteriorating employment opportunities for children in the agricultural sector. ${ }^{57}$ The participation rates of the children of miners and metalworkers declined in line with their contributions. The children of factory workers began with the highest participation rates and increased them from first to last. Con-

53 David Levine, "Industrialization and the Proletarian Family in England", Past and Present, 107 (1985), pp. 935-966.

4 Clark Nardinelli, "Child Labor and the Factory Acts", Journal of Economic History, 40 (1980), pp. 739-755, and Child Labor.

ss Here the sample is reduced to 903 households as we are only concerned with those that have at least one child resident. These households contain 3,841 children.

36 Participation is defined as either having an occupation coded or eamings recorded. A number of children did not have earnings recorded separately from those of older brothers or sisters or, in some cases, parents, so an earnings definition alone would understate the numbers working.

${ }^{37}$ See Allen, Enclosure and the Yeoman. 


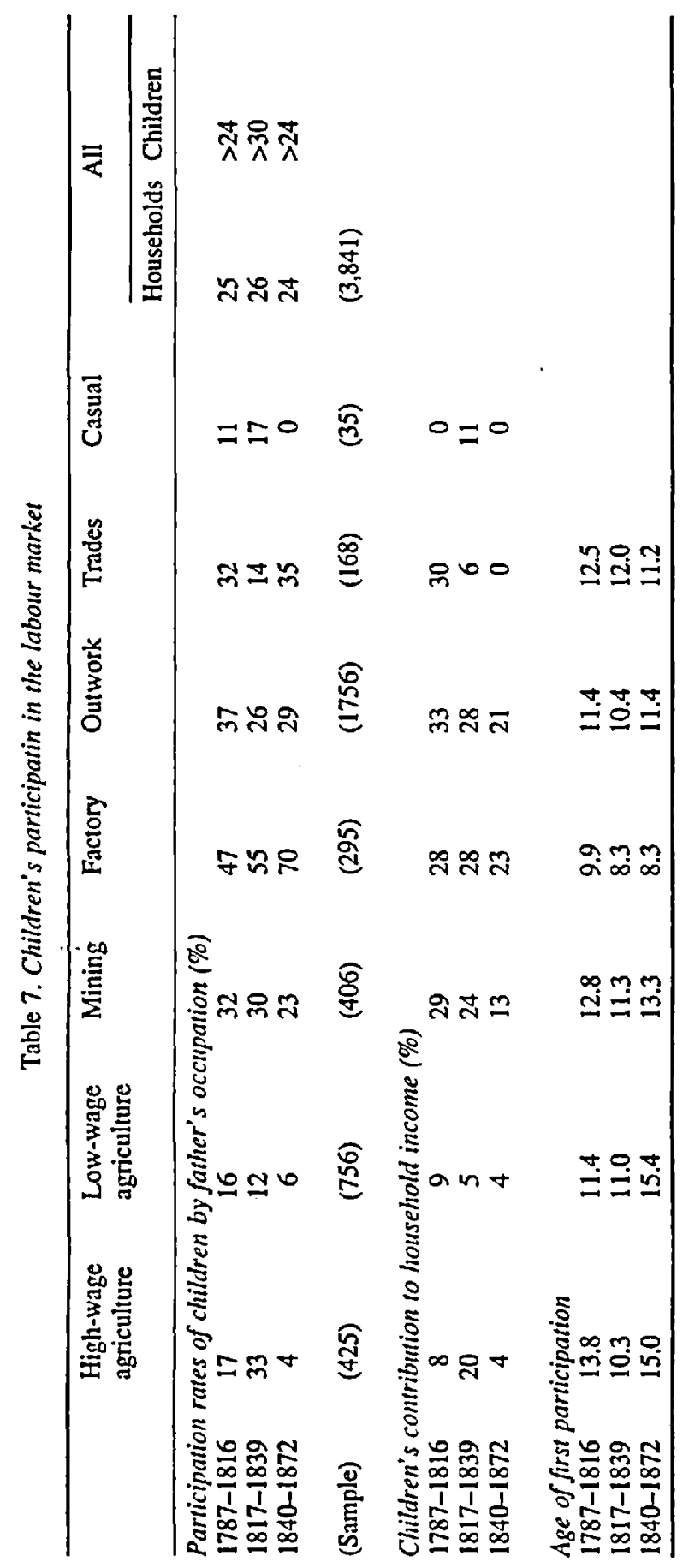


temporaries who believed that industrialization was increasing child labour probably had factory work in mind, although it was not representative. From initially high levels the participation rates of outworkers' children declined only to increase again slightly from $1817-1839$ to $1840-1872$, perhaps in response to the deterioration in their parents' relative (and in many cases) absolute status. The divergent trends in children's participation rates and contributions to family income in factory and outworking families after 1840 suggests that children's work was becoming less regular and/or less well paid. Perhaps it reflects shorter hours in factory employment as children were worked in relays to accommodate the Factory Acts. The relatively high participation of tradesmen's children in the final period should qualify the dramatic decline in contributions to family incomes recorded for this group in the sample where children's eamings can be separately identified. It is likely that children's contributions were larger for tradesmen than estimated, albeit in decline.

Table 7 provides estimates of participation rates for all children living in families based on the weighted averages of our occupationally-specific findings. ${ }^{58}$ The striking feature is the remarkable stability of the participation rate of children within families: one-quarter of whom worked through industrialization..$^{59}$ The decline in participation rates for the children of fathers in most occupational groups was offset by the shift of the adult population towards jobs associated with higher child activity rates. Although the absolute number of children working increased, along with population, this left the participation of children, at least of those in families, stable over time. How does this square with contemporary belief that children were working at younger ages which would appear inconsistent with the steady participation rates of children in households?

The budget data allows us to consider age-specific participation rates and to compute the age of first participation..$^{60}$ For all occupational groups the age at which children first became employed declined between the first and second time periods. Children were being sent to work at younger ages after the Napoleonic wars and the shift of the adult population towards occupations in which children's age at first participation was lower than average, for instance factory work, must have exaggerated the occupationally-specific trends.

\footnotetext{
ss The aggregate figures are obtained by estimating the proportion of males that would be heads of households with children, using male employment weights calculated for different years to weight the average experience, and using the average number of children in these households to obtain a national picture. For full details of this computation see Horrell and Humphries, "The Exploitation of Little Children", n. 16.

s9 Here we are only concemed with the numbers who do some work, not the amount of work performed. A stable participation rate is not necessarily an indicator of stable labour input from children.

${ }_{60}$ The full working for this computation can be found in Horrell and Humphries, "The Exploitation of Little Children", pp. 496-499.
} 
But if children were working at younger ages, why is this not reflected in the proportion of children in households who were working? Younger working might be expected to mean a higher proportion of children working. Examination of the ages of children in the sample households indicates that older children were leaving home earlier in the first four decades of industrialization. More under 20 year olds were living apart from families. By making the reasonable assumption that all children and adolescents who had left home were in the labour force, we calculated the participation rates of all children, that is those living in families and those living independently (Table 7).$^{61}$ While the actual numbers are subject to wide margins of error, the evidence suggests that in aggregate, including both children who lived with their families and those who had left home, participation rates rose between 1787-1816 and 1817-1839. The mechanism for the increase is supported by contemporary observation. For instance, Disraeli commented on the new fashion for children to leave home, move into lodgings and neglect their parents. ${ }^{62}$

Industrialization did involve more children working. But neither the mechanisms by which this change occurred nor its transience have been fully understood and for these reasons the links between children's employment and the rise of the breadwinner family system have been obscured. Industrialization did not significantly increase the relative number of children in families who were employed, although the absolute number rose dramatically given the increase in the relevant population. However, the larger proportion of under-19 year olds living apart from families in 1817-1839 boosted the participation rate of the child population. The younger age at leaving home meant that the stable proportion of working children in families was only achieved by younger children working. The larger proportion of teenagers living apart from families had knock-on effects on the age at which their younger brothers and sisters began employment. In this way increased child labour was not only the result of increased demand during the first phase of industrialization but also the product of a change in family structure in terms of larger numbers of older children living apart from their families. ${ }^{63}$ Older and younger children were substitutes in the labour market in families in some occupa-

61 Here we looked at the age structure of children in households compared with the population aged 0-19 in England and Wales to try to infer something about the age of leaving home. We find that the number of children estimated as living in households overstates child population 1787-1816, understates it 1817-1839 and overstates it again around midcentury, implying that more children were to be found outside homes in this middle period. For full details of these comparisons, see Horrell and Humphries, "The Exploitation of Little Children". The estimates of children working are very rough as they only look at the shortfall of the population under $\mathbf{2 0}$ missing from our households and assume these people are working outside the home.

${ }_{62}$ Benjamin Disraeli, Sybil (London, 1845).

${ }^{63}$ Although of course increased demand for juvenile labour underpinned the increased independence manifest in larger proportions of older children living apart from families. 
tions. The ability of younger children to work may have released older children from their familial obligations and allowed earlier independence. Alternatively, increasing real earnings for 15-19 year olds may have facilitated their independence and put pressure on young children to work if a certain proportion of child labourers was needed for family support. Whatever the underlying mechanism, pessimists who have seen industrialization forcing more children into the labour market and at younger ages carry the day. But this bulge in children's participation did not inhibit the developing dependence on men, for the participation rates within households were only maintained by younger children's employment and these childish workers could not replace the earnings of those older siblings who had sought independence. So, ironically, increased child labour coincided in the British case with men's earnings increasing in importance within family incomes.

Moreover, the increase in the aggregate participation rate was not maintained. The nexus of related variables, the proportion of children living outside families, the age at starting work and aggregate participation rates all moved in the opposite direction after 1840 . If there was a revolution in the relative incidence of child labour, it characterized only the crucible of industrialization from 1817-1839 and did not extend into the second half of the nineteenth century. Thereafter families retained older children, but lower participation rates even of children in families meant children's contributions continued to slide leaving families ever more dependent on men.

What threw the participation rates of children in reverse, reduced the independence of adolescents and raised the age at which children in families were sent to work? As we have seen in the context of married women's participation, economic theory posits that changes in wages are crucial in explaining participation decisions. But industrialization witnessed changing employment opportunities, the introduction of protective labour legislation, and changing attitudes to children's employment; all factors which may have independently affected the demand for and supply of child labourers.

Nardinelli explained the decline in children's participation in factory work after 1840 not by legislative changes but by rising male real earnings which allowed fathers to purchase leisure time for their children. ${ }^{64}$ Our weighted averages of participation rates of children in families do not decline despite increases in average adult male real earnings from the mid-1830s onwards, cautioning against an overemphasis on income effects as explanations of patterns in children's participation rates. Nor do the occupational experiences offer unambiguous support for Nardinelli's position. True, in mining and outworking families, increases in male real

o* Nardinelli, Child Labor, p. 154. 
wages were accompanied by declining child participation between the first and second time periods, and many occupations experienced increasing male real earnings from the 1840 s onwards when the participation of younger children in particular declined. Moreover, the increased participation of children with fathers in outwork from 1817-1839 to $1840-1872$ was accompanied by declining male earnings. However, children with fathers in factory work and trades exhibited increased participation alongside increased male earnings, indicating the importance of other explanatory factors. Indeed, participation of factory workers' children increased in all time periods, as did their earnings, whereas in low-wage agricultural families male earnings decreased until the 1840 s along with their children's participation. These exceptions point to the importance of the availability of jobs in determining the incidence of child labour, and suggest that children's work was the norm, performed if opportunities were available.

However, economic theory allows the possibility that children may not have left the labour market even if their fathers' eamings increased if their own wages were increasing faster. There is evidence in the budgets that children's eamings rose faster than male eamings initially but lost ground subsequently. Low-wage agriculture is the only exception. Thus children's participation could fit a relative earnings explanation. Children, or their parents, may have been choosing work over leisure in response to the increasing opportunity cost of leisure time. We estimate a model of children's labour supply to test this and related hypotheses. ${ }^{65}$

In modelling the decision to participate, the standard explanatory variables include the real earnings of other family members and non-wage income (expected to have negative effects), and the wage (or earnings) which the child could obtain in the labour market (expected to have a positive effect). The child's age is included to represent availability for work. But the individual child's labour force participation will also be part of a household's allocation decision and will reflect the relative preference for home production and for earned income, and each family member's comparative advantage in the labour market. To capture this effect the numbers of older and younger siblings and of other persons in the household are included. The presence of older children can be expected to decrease the probability of a child's participation at any given age as the income needs of the family were more likely to be met from the earnings of older siblings. More little brothers and sisters, and the presence of other people, for instance lodgers, can be expected to increase the productivity of any child in home production (child minding, cooking and so on). A

6s Full details of the technique used is given in Horrell and Humphries, "The Exploitation of Little Children". Gender differences in the relationship of children's participation to the family economy are also discussed. 
dummy variable for the mother working is included to capture any substitution between mothers and children in market work. ${ }^{66}$ In addition, dummy variables for fathers' occupations and occupationally-specific time trends are incorporated to capture variations in employment opportunities for children. Finally, composite variables which interact age with time and number of older children with time are included to pick up changes over time in the age of participation and the effect of older children on participation.

Various alternative specifications were tried and the final regression is reported in Table 8. For all children, some variables do have the expected effects. Father's earnings have a negative effect on participation and own earnings a positive effect. However, other family income, which should have a negative effect, has a positive and significant coefficient. This reflects the positive correlations across regions and over time between the employment opportunities facing any one child and those facing other family members. The probability of participation increases with age.

Household composition effects suggest that there was some substitution between older and younger children. The more older children there were in the family, the less likely was any one child to work as (presumably) income needs were satisfied by the participation of the older brothers or sisters. But the combined variable of number of older children and time suggests that this relationship was weakening. Earlier we noted that some families seem increasingly to have harboured older, non-working children. Perhaps this signifies gender overriding age as the main determinant of the order in which children worked. Significantly, there appear to have been few opportunities for children to be involved profitably in home production. The larger the number of younger children in the family the higher the probability of any individual child working in the market. Income needs dominated any useful role that could be played in child minding or home production more generally: a point also illustrated by the insignificant effect that the presence of others in the household had on participation, and by the apparent lack of substitution between children's and mother's waged work.

The time trend shows an increase in the probability of children working until 1807 and then a decrease, although the trend turns down earlier in agriculture (1798). The pattern is reversed for the children of factory workers who were more likely to work than other children throughout the whole period, but for whom the trend in participation declined until 1828 and then increased. These two occupationally-specific stories are readily explained. The early loss of children's employment in agriculture has been

${ }^{66}$ We do not expect this to be important. Consideration of mother's eamings relative to children's eamings shows mothers to be earning less once the children are over 10 years of age in all occupations. As children have an advantage over mothers in the labour market we would not expect to see children substituting for mothers in the home. 
Table 8. Probit equations of individual children's participation

\begin{tabular}{|c|c|c|}
\hline & All children & \\
\hline $\begin{array}{l}\text { Constant } \\
\text { Real eamings of father } \\
\text { Real other income } \\
\text { Predicted own real earnings }\end{array}$ & $\begin{array}{r}-1.542 \\
-0.008 \\
0.032 \\
0.073\end{array}$ & $\begin{array}{l}(-8.86)^{\circ} \\
(-2.11)^{3} \\
(8.13)^{\circ} \\
(2.03)^{4}\end{array}$ \\
\hline $\begin{array}{l}\text { Number of younger children } \\
\text { Number of older children } \\
\text { Other non-family household members } \\
\text { Mother works } \\
\text { Age of child }\end{array}$ & $\begin{array}{r}0.176 \\
-0.533 \\
-0.181 \\
-0.090 \\
0.060\end{array}$ & $\begin{array}{l}(7.69)^{*} \\
(-8.23)^{\circ} \\
(-1.57) \\
(-1.31) \\
(4.06)^{*}\end{array}$ \\
\hline $\begin{array}{l}\text { Time } \\
\text { Time }^{2} \\
\text { Factory dummy } \\
\text { Factory } x \text { time } \\
\text { Factory } x \text { time } \\
\text { Agriculture } x \text { time }\end{array}$ & $\begin{array}{l}0.013 \\
-0.00031 \\
2.986 \\
-0.131 \\
0.0017 \\
-0.0055\end{array}$ & $\begin{array}{l}(1.73)^{8} \\
(-3.55)^{4} \\
(2.74)^{*} \\
(-2.18)^{3} \\
(2.15)^{3} \\
(-2.07)^{4}\end{array}$ \\
\hline Number of older children $x$ time & 0.0037 & $(2.39)^{4}$ \\
\hline $\mathrm{X}^{2}$ & $1,653.4^{\circ}$ & \\
\hline Predicted correctly & $86.6 \%$ & \\
\hline Sample & 3,336 & \\
\hline
\end{tabular}

Notes:

- Indicates significance at 1 per cent level.

${ }^{3}$ Indicates significance level below 1 per cent and above 10 per cent; $t$-ratios in parentheses. The sample excludes children whose earnings were given only as a family total or with the earnings of the mother or other children.

widely noted. Parents may have resisted their children working in factories in the era of pauper apprentices and rural locations, but this resistance was overcome when employment became available in towns. ${ }^{67}$ The overall trend captures patterns in mining, outwork and trades. It suggests a general decline in employment opportunities for children ceteris paribus. Possible explanations include the decline in the apprenticeship system; the earlier transition to male breadwinner families in, say, trades and mining; and handloom weavers' aspiration to the lifestyle of the artisan when incomes rose but discovery that earnings opportunities for children were no longer there when adult earnings came down. The significance of these time trends is that explanations of the labour force participation of children during industrialization must go beyond wage and income effects.

${ }^{67}$ See Pinchbeck and Hewitt, Children in English Society, Nardinelli, "Child Labor and the Factory Acts". 


\section{FAMILIES WITHOUT MALE BREADWINNERS}

The overarching significance of men's earnings within family incomes indicates another enduring feature of the economic timescape: families which were without an adult male and/or his earning power were in grievous circumstances. ${ }^{68}$ In an earlier paper Humphries analysed a small sample of female-headed households and an even smaller sample of families whose male head was sick and not working. ${ }^{69}$ These families were poorer than families headed by men in almost all occupational groups with the possible exception of low-wage agriculture. Unfortunately this small sample is not spread evenly through the period of industrialization and we have complete evidence for only one family in each of the latter two sub-periods. But there is no evidence that these families improved their position relative to husband-wife households, a conclusion which is consistent with other independent evidence (see Table 9 compared with Tables 1 and 2)..$^{70}$ The inability of women and children in these families to sustain relative standards is further evidence that disappearing job opportunities for women and children, sluggish relative pay and institutional constraints on employment were characteristic of the period. This early feminization of poverty has the same economic and ideological roots as the darker path to dependence on men in families where they were present.

The participation rates of women in the sample of female-headed households were higher than those of wives of men in most occupational groups and held up over the course of industrialization (Tables 9 and 5). The participation rates of women married to men who were ill and not working were lower than those of wives of men in some occupational groups and lower than those of all wives. These women were older on average than the wives of working men, which might have contributed to this differential. Perhaps these families lived in areas of high unemployment or perhaps morbidity ran in families so unhealthy men were more likely to be married to unhealthy women, both explanations offered for the relatively low participation rates of the wives of unemployed men observed in modern data. ${ }^{71}$ Children in families headed by women and in families headed by men who were not able to work had higher participation rates than those in families with fathers present (Tables 9 and 7). The age structure of parti-

* A sample of families headed by women (widows, unmarried mothers and deserted wives) is studied in Jane Humphries, "Female-Headed Households in Early Industrial Britain: The Vanguard of the Proletariat", Labour History Review (forthcoming. 1998). Results from this paper will be cited where relevant.

6 lbid.

${ }^{70}$ See ibid. and sources cited therein.

"See Richard B. Davies, Peter Elias and Roger Penn, "The Relationship Between a Husband's Unemployment and His Wife's Participation in the Labour Force". Oxford Bulletin of Economics and Statistics, 54 (1992), pp. 145-171. 
The Case of Nineteenth-Century Britain

Table 9. Income and participation in female-headed households

\begin{tabular}{|c|c|c|c|c|c|}
\hline & $1787-1815$ & $1816-1820$ & $1821-1840$ & $1841-1845$ & $1846-1865$ \\
\hline $\begin{array}{l}\text { Family income } \\
\text { (f p.a.) }\end{array}$ & 40.1 & 30.8 & 26.9 & 19.0 & 40.3 \\
\hline $\begin{array}{l}\text { Real family income } \\
\left(\boldsymbol{f}_{\text {p.a. })^{*}}\right.\end{array}$ & 37.87 & 22.84 & 31.72 & 20.04 & 40.10 \\
\hline $\begin{array}{l}\text { Real adult-equivalent } \\
\text { family income } \\
\left.\text { ( } \boldsymbol{E}_{\text {p.a. }}\right)^{\mathrm{b}}\end{array}$ & 9.00 & 7.25 & 9.01 & 7.62 & 13.37 \\
\hline \multicolumn{6}{|l|}{ Contribution from (\%) } \\
\hline woman & 30.9 & 38.5 & 44.0 & 69.4 & 49.9 \\
\hline children & 50.3 & 45.3 & 38.2 & 25.0 & 43.3 \\
\hline $\begin{array}{l}\text { other sources } \\
\text { of which }\end{array}$ & 18.7 & 15.2 & 17.8 & 5.6 & 6.8 \\
\hline self-provisioning & 5.3 & 1.7 & 0.0 & 0.0 & 1.8 \\
\hline \multicolumn{6}{|l|}{ Participation rates: } \\
\hline children & 43.1 & 46.2 & 42.4 & 44.4 & 33.3 \\
\hline (Sample) & (19) & (59) & (25) & (4) & (4) \\
\hline
\end{tabular}

Noles:

"Deflated using cost-of-living index from Feinstein, "Nominal Wages", p. 26; 1820$1824=100$.

${ }^{b}$ Adult equivalents calculated as 1 for woman, 0.5 all other household members.

c Participation defined as earnings or occupation recorded.

cipation rates suggested that fatherless children or those with invalid or unemployed fathers began work at younger ages. More intensive working and working at younger ages was an economic exigency forced on families by inadequate or non-existent male earnings.

Female-headed households, on average, had higher non-earnings components of family incomes (Table 9). That poor relief was often important to such families is not surprising, but it is interesting that they made less use of self-provisioning than families with husbands present. Perhaps informal but vigilant means-testing of relief provision made femaleheaded households even more reluctant than husband-wife households to reveal income in kind; perhaps the urban bias of the sample disguises the self-provisioning undertaken by female-headed households in the countryside; perhaps these families faced a hierarchy of needs in which the demands for money income were pre-eminent, hence the high labour market participation rates which crowded out the use of time in selfprovisioning. The contribution which other sources of income made to families headed by sick or unemployed men was also distinctive. A high 
proportion of these families had access to other sources of income but self-provisioning was relatively unimportant. ${ }^{72}$ These families were able to tap forms of assistance which were unavailable to the female-headed households in similarly miserable circumstances, most notably sick clubs and friendly societies. They also sold and pawned possessions. The picture is one of families in disequilibrium; the other sources of income represent short-run responses to life crises, not long-run sustainable strategies for survival. Significantly even in these grim conditions their main lifelines continued to be the remnants of their husband/fathers' breadwinning: the subsidies from sick clubs and doles. In the prolonged absence of male earnings, of course, the situation had to be different. Either families went under, ceased to exist as independent entities, or women in particular increased their participation and with the help of their children struggled to some new miserable equilibrium, becoming in essence like the femaleheaded households in the sample. The welfare costs of the labour expended by the women and children in these families at this level of poverty were considerable. ${ }^{73}$

The experience of families without men's earnings and without men throws into relief an important historical conclusion: the presence of men in families, men's superior earnings power and even dependence on men had its benefits as well as its costs. The death or desertion of a father, as several working-class autobiographies of the period illustrate, threatened not only the material well-being of family members but the very existence of the family. ${ }^{74}$ But the experience of families headed or effectively headed by women uncovers another context in which women and children were the mainstays of family life: at times and in circumstances when men could or would not be breadwinners. The important point is that these times and circumstances were not unusual. Death or incapacity of the male household-head was commonplace given the mortality and morbidity of early industrial Britain. Desertion was probably also increasing at the end of the eighteenth century when the growing cities and expanding empire offered dissatisfied men a refuge and recruitment into the army or navy an escape route. ${ }^{75}$ Less dramatic, but probably just as disruptive, were the ordinary absences of men moved around in search of work. ${ }^{76}$ If we include such temporary separations, as well as cases where men were unable to

72 This was also true of the female-headed households.

73 See Sara Horrell, Jane Humphries and Hans-Joachim Voth, "Stature and Relative Deprivation: Fatherless Children in Early Industrial Britain", Continuity and Change (forthcoming, 1998).

${ }^{74}$ See David Vincent, Bread, Knowledge and Freedom: A Study of Nineteenth-Century Working Class Autobiography (London, 1981), ch. 4.

75 David A. Kent, " 'Gone for a Soldier': Family Breakdown and the Demography of Desertion in a London Parish, 1750-91", Local Population Studies, 45 (1990), pp. 27-42.

${ }^{76}$ Humphrey Southall, "The Tramping Artisan Revisited: Labour Mobility and Economic Distress in Early Victorian England", Economic History Review, XILIV (1991), pp. 272296. 
work because of chronic illness or who were long-term unemployed, and not forgetting men in the army and navy and in prison, Humphries estimates that about 20 per cent of families in early industrial Britain, were headed by women. ${ }^{77}$ Thus a large minority of people at any one point in time, and an even larger minority at some stage in their lifetimes, experienced family life without a breadwinner male. Despite a welfare system and an economy which operated by and large as though all households had such a prop, many of these families survived and lived to see a better day. It was a heroic achievement by the women and children involved.

\section{CONCLUSION}

Women's independence was eroded over the course of industrialization as families became increasingly dependent on men's earnings. The faltering of married women's own earned contributions to family income was only one part of this story. Economic and social changes weakened women's control over resources through several other channels. Opportunities to contribute substantially to the household through self-provisioning activities were curtailed and the earnings of children, which had previously been important in supporting the children themselves and might have been seen as the preserve of the mother, were also diminished. With these changes women, and children, became dependent on men instead of providing nonmarket, but tangible, resources for the household economy. The alterations seen in women's access to the means to contribute towards their families' well-being were felt most acutely by those households without male breadwinners, the female-headed households, whose relative status deteriorated. Although clearly showing the relative importance of men's earnings in family incomes, our study emphasizes how few households could rely entirely on a male breadwinner for their security. The prevalence of female-headed households and the inadequacy of male earnings to cover family needs in certain key stages of the life cycle show that for most families the participation of women and children in some circumstances or at some stages was essential for survival.

Our story has been one of a patchy, incomplete and sometimes miserable dependence on men and male eamings, with its origins clearly in the period before the Industrial Revolution and its genesis markedly different in families with different occupational identities and economic bases. Some families, such as miners, followed the beneficent route where legislation and high male earnings combined to create dependency. Others, like the families of outworkers and agricultural labourers, were forced along the darker route of low earnings and few opportunities for work. Yet others, for instance factory workers, eschewed the male breadwinner family form despite labour legislation and high earnings. Their family

$\pi$ Humphries, "Female-Headed Households". 
structure was more influenced by employment opportunities, local norms and the relatively high material living standards which women's and children's contributions afforded. The evidence does not support those grand theorizations which depict either capitalism or industrialization as inaugurating an era of dependence and degradation for women, nor does it show a universality of patriarchal subservience. Instead it offers support to newer themes emerging in family and gender history.

First, it suggests that historians of the family might be well advised to question periodization adopted from mainstream narratives and think instead of the continuities and discontinuities evident in their own imperfectly reconstructed worlds. Although our analysis implicates economic changes in the origins and expansion of the male breadwinner family, it does so in an occupationally and regionally differentiated way and on a timescale not transparently linked to "the Industrial Revolution" as conventionally dated. Second, our evidence is consistent with a more general rejection of attempts to produce all-encompassing frameworks for and explanations of social phenomena, represented here both by the economistic modelling of labour supply and the feminist emphasis on intentional exclusion. Grand theorizations of the rise of the male breadwinner family provide falsely homogenizing accounts which are obsessed with monocausality, outcomes and finished worlds. We cannot read backwards from those circumstances which promote the male breadwinner family today to its origins. Finally, it supports the rejection of any claim that there can be a specific cause of transition to male breadwinning and highlights the pluralistic and multifaceted nature of the family in the past. 